\title{
Oxygen Fugacity and Volatile Content of Syntectonic Magmatism in the Neoarchean Abitibi Greenstone Belt, Superior Province, Canada
}

\author{
Baptiste Madon ${ }^{1, *}$, Lucie Mathieu ${ }^{1,2}$ and Jeffrey H. Marsh ${ }^{3}$ \\ 1 Département des Sciences Appliquées (DSA), Centre d'Étude sur les Ressources Minérales (CERM), \\ Université du Québec à Chicoutimi (UQAC), Chicoutimi, QC G7H 2B1, Canada; Lucie1_Mathieu@uqac.ca \\ 2 Chaire institutionnelle UQAC sur les Processus Métallogéniques Archéens, Université du Québec à \\ Chicoutimi (UQAC), Chicoutimi, QC G7H 2B1, Canada \\ 3 Mineral Exploration Research Centre, Harquail School of Earth Sciences, Laurentian University Sudbury, \\ Sudbury, ON P3E 2C6, Canada; jmarsh@laurentian.ca \\ * Correspondence: baptiste.madon@gmail.com
}

Received: 27 September 2020; Accepted: 26 October 2020; Published: 28 October 2020

check for updates

\begin{abstract}
Neoarchean syntectonic intrusions from the Chibougamau area, northeastern Abitibi Subprovince (greenstone belt), may be genetically related to intrusion related gold mineralization. These magmatic-hydrothermal systems share common features with orogenic gold deposits, such as spatial and temporal association with syntectonic magmatism. Genetic association with magmatism, however, remains controversial for many greenstone belt hosted Au deposits. To precisely identify the link between syntectonic magmas and gold mineralization in the Abitibi Subprovince, major and trace-element compositions of whole rock, zircon, apatite, and amphibole grains were measured for five intrusions in the Chibougamau area; the Anville, Saussure, Chevrillon, Opémisca, and Lac Line Plutons. The selected intrusions are representative of the chemical diversity of synvolcanic (TTG suite) and syntectonic (e.g., sanukitoid, alkaline intrusion) magmatism. Chemical data enable calculation of oxygen fugacity and volatile content, and these parameters were interpreted using data collected by electron microprobe and laser ablation-inductively coupled plasma-mass spectrometry. The zircon and apatite data and associated oxygen fugacity values in magma indicate that the youngest magmas are the most oxidized. Moreover, similar oxygen fugacity and high volatile content for both the Saussure Pluton and the mineralized Lac Line intrusion may indicate a possible prospective mineralized system associated with the syntectonic Saussure intrusion.
\end{abstract}

Keywords: oxygen fugacity; volatile content; syntectonic intrusions; Abitibi greenstone belt

\section{Introduction}

The Abitibi Subprovince (greenstone belt), Superior craton, is a gold-endowed greenstone belt where gold is mostly concentrated within volcanogenic massive sulfide (VMS) and orogenic gold systems. In addition, intermediate to felsic alkaline intrusions, such as monzonite and syenite, may provide fluids and metals to intrusion related gold system (IRGS) [1]. As IRGS and orogenic gold deposits formed during the syntectonic period and display some similarities (e.g., mineralized quartz veins), the influx of magmatic fluid in many gold systems is debated. For example, the Canadian Malartic deposit was first interpreted as an IRGS, re-interpreted as an orogenic gold system [1,2] and was then described as a complex association of both genetic models [3]. Thus, Archean IRGS and orogenic gold systems may be hard to distinguish [4], rendering difficult the application of a single, mutually exclusive exploration model. 
IRGSs are generally polymetallic and gold-dominated magmatic-hydrothermal systems centered on intrusions, e.g., Beattie syenite [5,6]. Metals distribution is generally zoned with hydrothermal alteration having a limited extent and potentially including K-metasomatism. Mineralization generally consists of sheeted auriferous quartz veins $(\mathrm{W}, \mathrm{Cu}, \mathrm{Zn}, \mathrm{Au})$, skarns $(\mathrm{Au}, \mathrm{Bi}, \mathrm{Cu}, \mathrm{W})$, mineralized dykes, and disseminated sulfides [1,2]. Moreover, in the IRGS metallogenic model, magma is envisaged to carry metals through the crust. Experimental studies on silicate magmas show that Au solubility and the melt capacity to transport gold increases as the $\mathrm{Cl}$ and/or S-content of the melt increases. Moreover, the formation of $\mathrm{Au}$ bearing $\mathrm{Cl}$ - and/or S-complexes, in magmas, is linked to a narrow range of oxygen fugacity, i.e., $\triangle F M Q+0.5$ to $\triangle F M Q+1.5$, where FMQ refers to the fayalite-magnetite-quartz buffer [7-9]. In summary, the volatile and metal contents, as well as the $f \mathrm{O}_{2}$ of the magma, need to be constrained to determine whether syntectonic magmatism can transport $\mathrm{Au}$ and fertilize the upper crust, and whether the IRGS metallogenic model is realistic.

Most of the gold deposits (orogenic Au, IRGS) in the Abitibi Subprovince are present along the Cadillac fault; however, these systems generally have complex overprinting relationships, rendering hard the study of early IRGS. For that reason, this study focuses on the Chibougamau area, where a variety of syntectonic magma types (sanukitoid, alkaline intrusions, granitoid) are observed, and gold deposits are not overprinted by features characteristic of orogenic gold systems - a mineralizing style that is not abundant in the study area. Furthermore, magmatic-hydrothermal systems are unusually abundant in the Chibougamau area (e.g., central camp, MOP-II, Lac Line mineralization) [10-12], although the tectonic processes causing this remain unclear $[13,14]$. The abundance of such mineralizing systems in this area offers a unique opportunity to study the chemistry of 'fertile' magma intrusions. This contribution will mainly focus on constraining the $f \mathrm{O}_{2}$ parameter and the volatile content for a variety of syntectonic magmas.

To address these issues, this work presents a detailed study of the geochemical characteristics of one synvolcanic and four syntectonic intrusions. Uranium-Pb dating was conducted to validate the syntectonic age of undated intrusions. The trace elements chemistry of zircon and apatite is used to evaluate the $\mathrm{fO}_{2}$ of the melts and this study provides a basis for a systematic measurement of this parameter in Neoarchean intrusions. Moreover, the data are used to evaluate the economic potential of the studied intrusions.

\section{Geological Setting}

\subsection{Abitibi Subprovince and Chibougamau Area}

The Abitibi Subprovince, southern Superior Province, Canada, is a Neoarchean granitoid-greenstone belt composed of $40 \%$ intermediate to felsic intrusions and $36 \%$ volcanic rocks with the remaining $24 \%$ composed of sedimentary rocks, gneisses with undocumented protoliths and mafic to ultramafic intrusions [13]. In greenstone belts, such as the Abitibi Subprovince, magmatic activity mostly occurs in two main stages, during the synvolcanic (pre-2750 Ma to $2704 \mathrm{Ma}$ ) and the syntectonic periods (2704 Ma to $2690 \mathrm{Ma}$ ) [15,16]. The synvolcanic period is the main period of magmatism and is characterized by large volume volcanism, as well as tonalite-trondhjemite-granodiorite (TTG) and TT-diorite (TTD) intrusive suites [10]. This is followed by the syntectonic period, which is characterized by deformation, erosion-sedimentation, and orogenic gold style of mineralization [17,18]. Syntectonic magmatism is typically K-richer and has a limited volume (plutons, plugs, and subordinate volcanism) compared to TTG and TTD suites $[19,20]$. The main magma types of the syntectonic period are K-rich TTG, alkaline series, sanukitoids, biotite and two-mica granitoids, as well as high-K calc-alkaline (HKCA) intrusions [19,21]. The petrogenetic evolution of these magmas is debated [19]. Intermediate to felsic alkaline magmas (mainly monzonite and syenite) may actively participate in generating fluids and metal budgets to gold mineralizing systems of the syntectonic period, i.e., IRGS [1].

Syntectonic magmatism is ubiquitous in the Abitibi Subprovince. This study focuses on the Chibougamau area because (1) it displays a variety of magma types (sanukitoid, alkaline intrusions, 
granodiorite, shoshonite lava flows) and (2) magmatic-hydrothermal mineralizing systems are not significantly overprinted by orogenic gold systems, which are not abundant in the study area [10-12]. These characteristics offer a unique opportunity to study the $f \mathrm{O}_{2}$ of mineralized and un-mineralized intrusive systems that we assume representative of synvolcanic and syntectonic magmatism.

In the Chibougamau area, as in the rest of the Abitibi Subprovince, rocks have been metamorphosed to greenschist facies or higher grade, although the prefix 'meta-' is omitted from rock names. The Chibougamau area is located in the northeastern corner of the Abitibi Subprovince and is bounded by the Opatica Subprovince to the north and the Proterozoic Grenville orogeny to the east (Figure 1). In the Chibougamau area, the synvolcanic and syntectonic periods extend from $>2730$ to ca. $2710 \mathrm{Ma}$ and from 2704 to $2690 \mathrm{Ma}$, respectively [22]. The oldest volcanic rocks belong to the Des Vents (2798.7 \pm 0.7 Ma [23]) and Chrissie (2791.4 $\pm 2.9 \mathrm{Ma}$ [24]) formations. These rocks are overlain by volcanic cycles 1 and 2 of the Roy Group [22]. Volcanic cycle 1 consists mostly of undated mafic lava flows of the Obatogamau Formation [25] and intermediate to felsic lava flows of the Waconichi Formation $(2729.0 \pm 1.1$ Ma [25,26]). Volcanic cycle 2 is characterized by mafic rocks of the Bruneau Formation (2724.4 \pm 1.2 Ma [23]), felsic rocks of the Blondeau Formation $(<2724.4 \pm 1.2 \mathrm{Ma}[27])$ and by the intermediate to felsic volcanoclastic and sedimentary units of the undated Bordeleau Formation [10]. The synvolcanic period is also characterized by large volume TTG suites (e.g., La Dauversière Pluton) [28] and TTD suites such as the Eau Jaune Complex [29,30] and the Chibougamau Pluton [10] (Figure 1).

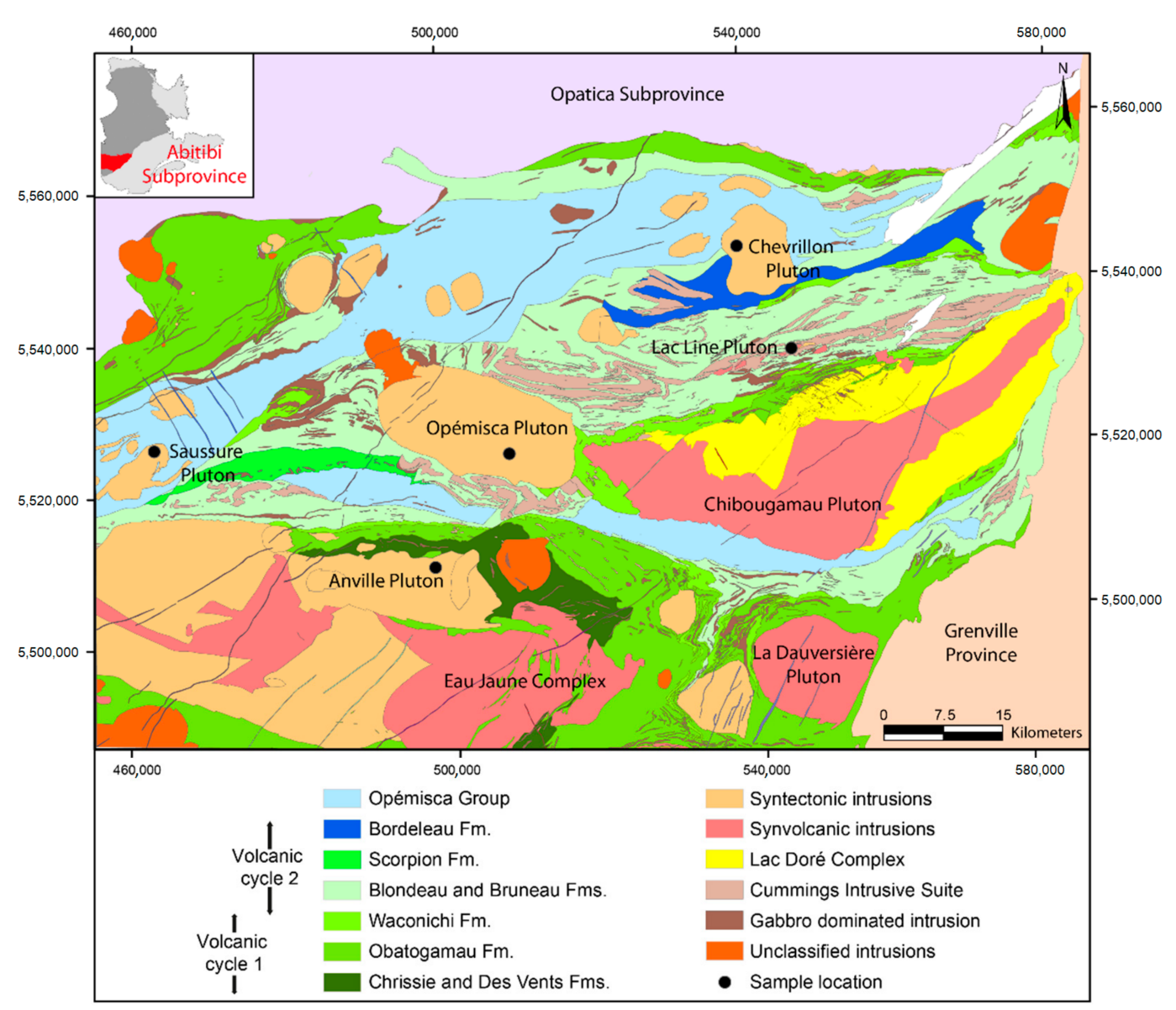

Figure 1. Geological map of the Chibougamau area showing the studied intrusions and the main volcanic and sedimentary sequences. The geological map is modified from the Ministère de l'Énergie et des Ressources Naturelles (MERN), Québec (SIGEOM, 2018). The projection is in North American Datum (NAD) 1983 Zone 18 N. 
During the syntectonic period, basin-restricted sedimentation formed the Opémisca Group. This group is mostly made of clastic sedimentary rocks (conglomerate, sandstone). The Opémisca Group comprises the Stella Formation and the lava flow-bearing (shoshonite) Haüy Formation $(<2691.7 \pm 2.9 \mathrm{Ma}$ [31]). The maximum deposition age for the Stella Formation is $2704 \pm 2 \mathrm{Ma}$, according to dating (thermal ionization mass spectrometry isotopic dilution, ID-TIMS, on zircon) performed on a conglomerate [27]. In the northern and western part of the study area, the Opémisca Group comprises the Chebistuan [22,32] and Daubrée [33,34] formations, respectively. Several intrusions, such as the Muscocho Pluton (2701.2 \pm 1.7 Ma [25]), formed during the syntectonic period (Figure 1).

\subsection{Syntectonic Magmatism in the Chibougamau Area}

The Chibougamau area contains a variety of syntectonic intrusions, such as alkaline, calc-alkaline, and sanukitoïd plutons. Representative intrusions for each category are selected for the need of this study. The selected intrusions are emplaced within either the sedimentary rocks of the Opémisca Group—granodiorite of the Chevrillon Pluton and alkaline Saussure intrusion—or within the volcanic rocks of the Roy Group-Opémisca Pluton (sanukitoid), Anville Pluton (TTG suite), and the Au-Cu-Ag mineralized Lac Line intrusion.

The undated Saussure intrusion is located in the western part of the northern Opémisca basin (Figure 1). This 9 by $3.5 \mathrm{~km}$ intrusion is elongated in the NE-SW direction. It cuts, and is, therefore, younger than the sedimentary rocks of the 2693.6 \pm 0.6 Ma Daubrée Formation [35], as well as undated diorite sills.

The Opémisca Pluton is located west of the Chibougamau Pluton and corresponds to a 25 by $11 \mathrm{~km}$ intrusion elongated in the WNW-ESE direction (Figure 1). The Opémisca Pluton is emplaced in volcanic, volcanoclastic, and sedimentary rocks, including the Blondeau and Bruneau formations [23,36]. The pluton has an age of $2697 \pm 2 \mathrm{Ma}$ [37] and is coeval with the other sanukitoid pluton of the Chibougamau area, i.e., the $2697 \pm 3$ Ma Barlow Pluton [38] (both are zircon U-Pb ID-TIMS ages).

The Lac Line intrusion is a small volume felsic to intermediate intrusive stock emplaced into the volcanic and volcanoclastic rocks of the Blondeau Formation (Figure 1). This intrusion has a zircon U-Pb TIMS age of $2707.6 \pm 1.4 \mathrm{Ma}$ [11] and formed during the transition between the synvolcanic and syntectonic periods [11].

The Chevrillon Pluton is located $6 \mathrm{~km}$ south of the Opatica Subprovince. This pluton is a 11 to $8 \mathrm{~km}$ intrusion elongated in the N-S direction (Figure 1). The pluton is emplaced into felsic to mafic volcanic rocks of the Bruneau and Bordeleau formations [39,40] and sedimentary rocks of the Chebistuan Formation [27]. The pluton recorded a limited amount of deformation, and likely formed toward the end of the syntectonic period, as shown by underdeveloped foliation and the lack of deformation of the quartz grain [41].

The Anville intrusion is 25 by $8 \mathrm{~km}$ long and is elongated in the E-W direction. It is intruded into the tonalite gneisses of the Lapparent Massif (2714 $\pm 2.5 \mathrm{Ma}$, ID-TIMS on zircon) [25] and into mafic volcanic rocks of the Chrissie and Obatogamau formations (Figure 1). The Anville intrusion is, locally, relatively undeformed compared to the Lapparent massif and the pluton may correspond, at least in part, to a syntectonic intrusion. However, recent geochronological investigations estimate that the Anville intrusion crystallized at $2714.8 \pm 0.6 \mathrm{Ma}$ [16]. The area mapped as the Anville Pluton may consists of several intrusions emplaced during the synvolcanic and syntectonic periods [42,43].

\section{Methodology}

\subsection{Sampling}

Eight samples were collected in the Chibougamau area from the Saussure, Opémisca, Lac Line, Chevrillon, and Anville intrusions during summer 2018 (Figure 1, Table 1). Only fresh rocks were sampled to avoid secondary processes that may affect the trace element chemistry of zircon and apatite. Alteration minerals, however, are observed in samples from the Lac Line intrusion that is entirely 
composed of hydrothermally altered rocks. A review of the literature about the petrography of the selected samples is proposed in the following section.

Table 1. Localization and lithology of the studied intrusions

\begin{tabular}{|c|c|c|c|c|c|c|c|}
\hline Intrusions & UTME * & UTMN * & Zone & Sample & $\begin{array}{l}\text { Whole-Rock } \\
\text { Geochemistry }\end{array}$ & $\begin{array}{l}\text { Apatite and Zircon } \\
\text { Compositions }\end{array}$ & $\begin{array}{l}\text { Dating U-Pb } \\
\text { Geochronology }\end{array}$ \\
\hline Saussure & 467,051 & $5,526,000$ & 18 & Granite & Figure 2 & Figures 5,7 ; Tables 2,3 & Figure 11 \\
\hline Saussure & 466,402 & $5,526,084$ & 18 & Quartz-rich syenite & Figure 2 & Figures 5,7 ; Tables 2,3 & Figure 11 \\
\hline Saussure & 463,895 & $5,526,093$ & 18 & Pegmatitic syenite & Figure 2 & Figures 5, 7; Tables 2, 3 & Figure 11 \\
\hline Chevrillon & 540,371 & $5,5473,39$ & 18 & $\begin{array}{l}\text { Quartz-rich } \\
\text { monzodiorite }\end{array}$ & Figure 2 & Figures 5, 7; Tables 2, 3 & Figure 11 \\
\hline Lac Line & 548,644 & $5,533,262$ & 18 & Tonalite & Figure 2 & Figures 5, 7; Tables 2, 3 & - \\
\hline Opémisca & 511,694 & $5,520,891$ & 18 & Qz-rich monzonite & Figure 2 & Figures 5, 7; Tables 2, 3 & - \\
\hline Anville & 497,685 & $5,509,637$ & 18 & Granodiorite & Figure 2 & Figures 5,7 ; Tables 2,3 & Figure 11 \\
\hline
\end{tabular}

The Saussure intrusion is made of three fractionated and concentrically organized intrusive phases. From the margin towards the core, these phases are a granite, a quartz-rich syenite, and a pegmatitic syenite [44]. The granite phase is made of $60 \%$ to $70 \%$ of K-feldspar and plagioclase, $15 \%$ to $20 \%$ of quartz and $10 \%$ to $15 \%$ of mafic mineral (Figure $2 \mathrm{c}$ ). The quartz-rich syenite is made of $85 \%$ of sodic plagioclase and microcline with strong oscillatory zoning, $5 \%$ to $10 \%$ of quartz, and $2 \%$ to $7 \%$ of mafic minerals (mostly biotite, magnetite, hematite, and amphibole). The pegmatitic syenite consists of $90 \%$ of zoned sodic plagioclase and potassic feldspar, 5\% of mafic minerals (biotite and amphibole), and 5\% of quartz (Figure 2a). Accessory minerals include titanite, zircon, apatite, and magnetite.

Lac Line is a multiphase intrusion mostly made of a porphyritic and equigranular tonalite. The other intrusive phases are a porphyritic syenite and a diorite observed in contact with tonalite dykes. The Lac Line stock is associated with polymetallic mineralization (Au-Cu-Ag $\pm \mathrm{Mo}$ ) [45] observed in the eastern part of the tonalite phase. The mineralization is characterized by quartz-sulfide-bearing veins associated with séricitisation $[11,45]$. The studied tonalite (Figure $2 \mathrm{~b}$ ) is made of 40 to $65 \%$ of phenocrysts of plagioclase, $20 \%$ to $30 \%$ of quartz, as well as $5 \%$ to $10 \%$ of biotite and amphibole. Plagioclase is strongly sericitized, whereas hornblende recrystallized into an assemblage of carbonate, chlorite, and actinolite [11]. Accessory minerals include zircon, apatite, and up to 5\% of disseminated pyrite.

The Opémisca Pluton is made of quartz-bearing monzonite in his inner parts and quartz-bearing syenite in his outer parts. The monzonite phase (Figure $2 \mathrm{~d}$ ) on which this study is focused is made of $50 \%$ to $60 \%$ of albite and oligoclase, $15 \%$ to $25 \%$ of perthitic K-feldspar, $13 \%$ to $18 \%$ of quartz, $2 \%$ to $10 \%$ of hornblende and minor amount of biotite $[46,47]$. Accessory minerals include zircon, apatite, titanite, oxide minerals, and epidote.

The Chevrillon Pluton is mostly made of K-feldspar phenocryst-bearing granodiorite. The matrix is made of $35 \%$ to $40 \%$ of plagioclase, $25 \%$ to $30 \%$ of microcline, and $10 \%$ to $15 \%$ of quartz (Figure 2 e). It also contains $15 \%$ of mafic minerals including biotite, chloritized hornblende, and epidote with allanite core. Accessory minerals correspond to titanite, zircon, apatite, and Fe-oxides [41].

The Anville intrusion is mostly made of tonalite transitioning gradually into granodiorite to the west. This study focuses on the granodiorite phase (Figure $2 \mathrm{f}$ ), which is made of $25 \%$ of quartz, $40 \%$ to $45 \%$ of albite-oligoclase and $10 \%$ to $15 \%$ of microcline, as well as $10 \%$ of biotite and hornblende [32,48]. Accessory minerals include zircon, apatite, epidote, allanite, and ilmenite.

For each intrusion, petrographic observations were performed on standard (30 $\mu \mathrm{m}$ thick) polished thin sections to document the texture of accessory phases and the contact relationships between apatite and silicates. Modal proportions were estimated visually on the microscope by counting 200 points (Table 2). Apatite was then imaged using a petrographic microscope equipped with cathodoluminescence (CL), i.e., CL8200 Mk5-1 Optical instrument (Cambridge Image Technology Ltd. CITL, Hertfordshire, UK). 
For each intrusion, zircon separates were obtained from 5 to $10 \mathrm{~kg}$ samples. The rocks were disaggregated (1 mm grains) using the electric pulse method at the Overburden Drilling Management Ltd. (ODM) laboratory (Ottawa, ON, Canada). Zircons were then separated using a shaking table and heavy liquids with densities of 3.0 and 3.3. Zircon grains of various shape and size (up to $300 \mu \mathrm{m}$ ) were then hand-picked dry using a binocular microscope. The most representative grains were selected and mounted using epoxy resin, and the mounts were polished to expose the cores of the zircons. Prior to analysis, CL and back scattered electron (BSE) images were obtained using a Tescan Vega 3 scanning electron microscope (SEM) at the Mineral Exploration Research Centre, Laurentian University (Sudbury, ON, Canada). Inherited cores and porous grains were avoided during the analyses.

\subsection{Whole Rock Analyses}

Whole rock chemical analyses were performed on all the samples collected in the field (Table 1). The whole rock analyses were performed by ALS Canada Ltd. Laboratory (Vancouver, BC, Canada). Major elements were determined by inductively coupled plasma (ICP) atomic emission spectroscopy (AES) after Li-borate fusion. Trace elements concentrations were quantified using an ICP-mass spectrometer (MS). Loss on ignition (LOI) was measured after heating samples at $1000{ }^{\circ} \mathrm{C}$. A duplicate performed on a sample from the Anville intrusion shows precision of $1 \%$ for all major elements and of $10 \%$ for trace elements, including rare earth elements (REE). Analytical accuracy and precision were monitored using the standard materials: OREAS-105 [49], SRM88B [50], AMIS0304, and AMIS0085 [51] for major and trace elements. An additional 30 whole rock chemical analyses were compiled from the SIGEOM dataset [52].

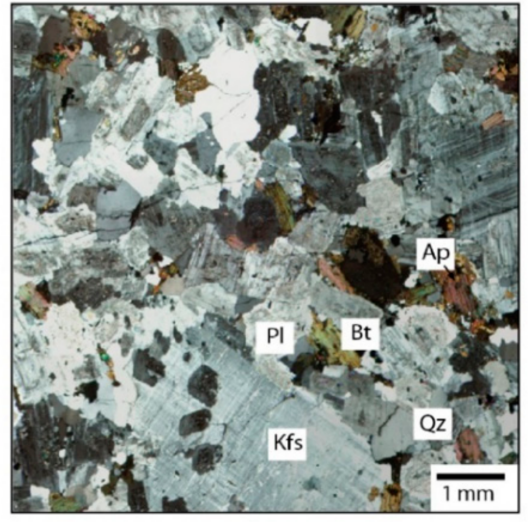

(a)

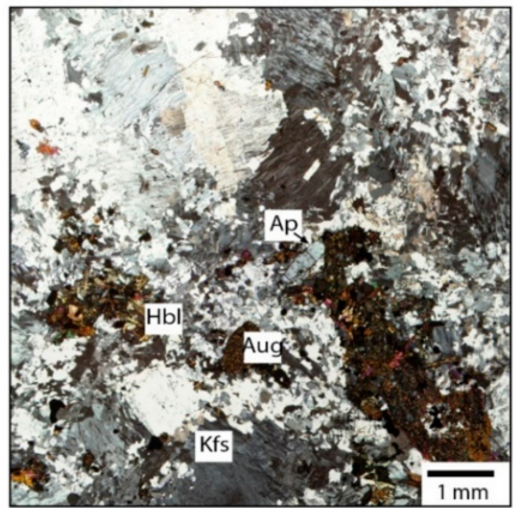

(c)

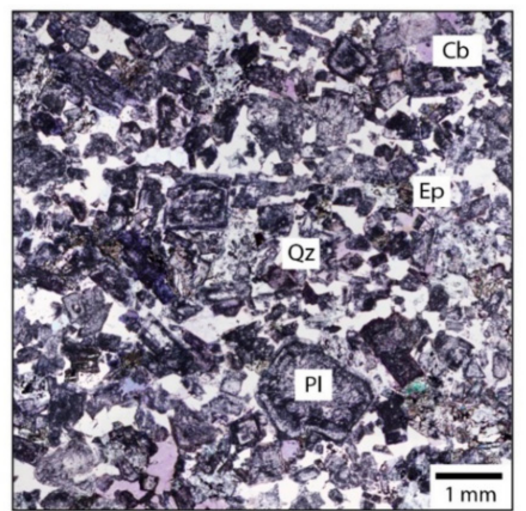

(b)

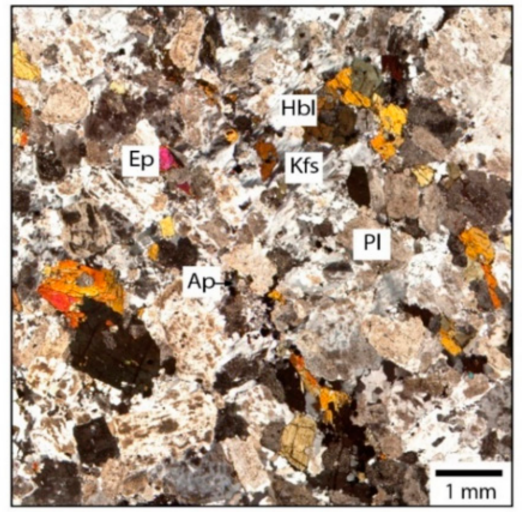

(d)

Figure 2. Cont. 


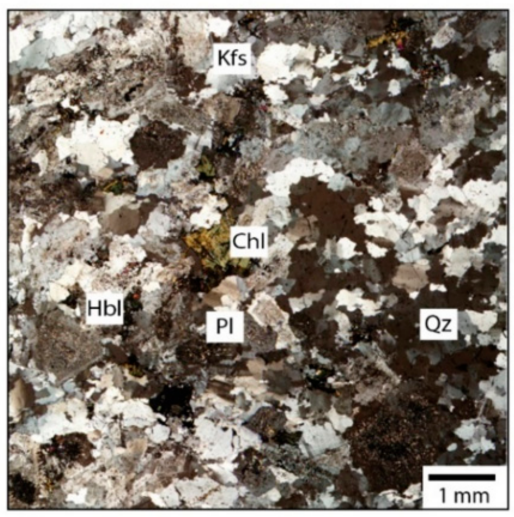

(e)

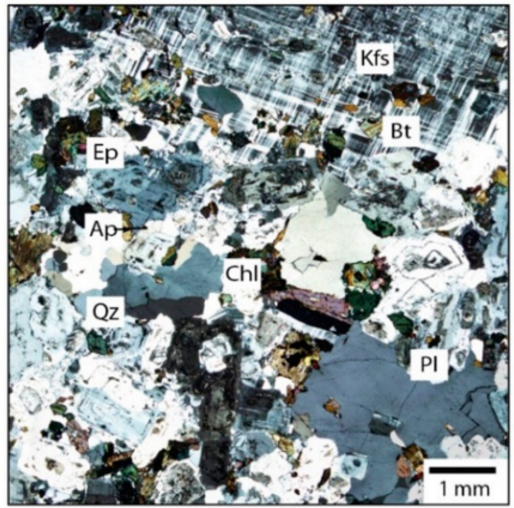

(f)

Figure 2. Photography of samples observed under polarized light and showing the main paragenesis of the (a-c) Saussure, (b) Lac Line, (d) Opémisca, (e) Chevrillon, and (f) Anville intrusions. Abbreviations are from Whitney and Evans [53] and stand for apatite (Ap), augite (Aug), biotite (Bt), carbonate (Cb), chlorite (Chl), epidote (Ep), hornblende ( $\mathrm{Hbl}), \mathrm{K}$-feldspar (Kfs), plagioclase (Pl), quartz (Qz).

Table 2. Modal composition of the studied samples. Abbreviations are from Whitney and Evans [53].

\begin{tabular}{|c|c|c|c|}
\hline Intrusion & Lithology & Mineralogy & Accessory Minerals \\
\hline Saussure & Qz-rich syenite & $\begin{array}{c}40 \% \mathrm{Kfs}, 30 \% \mathrm{Pl}, 10-12 \% \mathrm{Qz} \\
18 \% \mathrm{Bt}-\mathrm{Hbl}\end{array}$ & Ttn, Zrn, Ap, Iox \\
\hline Opémisca & $\begin{array}{l}\text { Qz-rich } \\
\text { monzonite }\end{array}$ & $\begin{array}{c}50-60 \% \mathrm{Pl}, 15-20 \% \mathrm{Kfs}, 10-15 \% \mathrm{Qz}, \\
5-10 \% \mathrm{Hbl}\end{array}$ & Ep, Ttn, Mag, Ap, Zrn \\
\hline Lac Line & Tonalite & $\begin{array}{c}>50 \% \mathrm{Pl}, 30-35 \% \mathrm{Qz}, 10-12 \% \mathrm{Cb} \\
5-7 \% \mathrm{Bt}-\mathrm{Chl}\end{array}$ & Zrn, Ap, \\
\hline Chevrillon & $\begin{array}{l}\text { Qz-rich } \\
\text { monzodiorite }\end{array}$ & $\begin{array}{c}50-55 \% \mathrm{Pl}, 10-20 \% \mathrm{Kfs}, 10-20 \% \mathrm{Qz}, \\
5-8 \% \mathrm{Bt}-\mathrm{Hbl}\end{array}$ & Ep, Ttn, Mag, Ap, Zrn \\
\hline Anville & Granodiorite & $\begin{array}{c}40-45 \% \text { Qz, } 30-40 \% \text { Pl, } 10-15 \% \text { Kfs, } \\
<5 \% \text { Bt-Chl }\end{array}$ & Zrn, Ap, Ep, Ilm, Alu \\
\hline
\end{tabular}

\subsection{Mineral Chemistry}

Electron microprobe analyses (EMPA) were performed on apatite and amphibole, using a fully automated CAMECA SX-100 electron microprobe equipped with five wavelengths dispersive spectrometers at the Laboratory of Microanalyses of the Geology Department of Laval University (Québec, QC, Canada). Time of acquisition for the analyzed elements are presented in the Supplementary Material Table S1. The microprobe was set to a current of $20 \mathrm{nA}$ and to a voltage of $15 \mathrm{kV}$. Apatite and amphibole grains were analyzed with a 5- $\mu \mathrm{m}$ diameter focused beam. Natural and synthetic standard materials were used for calibration including the Durango apatite that was used for Ca, P, and F calibration [54] (Supplementary Material Table S1).

Apatite and zircon were then analyzed for trace elements using the laser ablation (LA) ICP-MS system at the LabMaTer (Earth's Material Laboratory) laboratory of UQAC (Saguenay, QC, Canada). The LA-ICP-MS instrument used is an ArF Resolution M-50 Excimer (193 nm) laser coupled with an Agilent 7900X Q-ICP-MS. Apatite and zircon were analyzed using spots with diameters of 25-33 $\mu \mathrm{m}$ and 11-25 $\mu \mathrm{m}$, respectively. Masses and time of acquisition for the analyzed elements are presented in the Supplementary Material Table S1. The analyzed areas were carefully selected to avoid inclusions, inherited cores (zircon), and altered cracks. Laser repetition rate of $15 \mathrm{~Hz}$ and a fluence of $5 \mathrm{~J} \cdot \mathrm{cm}^{2}$ (measured) were used. Data were recorded for $60 \mathrm{~s}$ after $30 \mathrm{~s}$ of gas analysis (blank). Data quality (precision and accuracy) was monitored using the NIST 610, NIST 612, GSE, Durango, GSD and 91500 zircon reference materials [55]. The results are in good agreement with expected values except for Li (Durango), P, K, Fe, Ni (NIST standards and GSE) and Pt (GSD, NIST 610, NIST 612) (Supplementary Material Table S1). 
Ablation data for apatite and zircon were then reduced using the LADR 1.1.01 (http://norris.org. au/ladr) and Iolite software Version 4, (https://iolite-software.com), respectively. The internal standards are Ca (average value for each sample measured using electron probe micro analyzer, EPMA) and stoichiometric Si-content (15.28 wt.\% Si) for apatite and zircon, respectively. The internal standard for apatite has a value of 37.1 to $39.5 \mathrm{wt}$ \% Ca according to EPMA analyses. For apatite grains lacking EPMA data, a median value of $38.7 \mathrm{wt} . \%$ Ca was used as an internal standard.

Prior to data processing, pristine and non-pristine zircons are identified using a preexisting method, proposed by Zeh and collaborators [56]; Turlin and collaborators [57]; and Groulier and collaborators [58]. The pristine and non-pristine grains are distinguished using CL and BSE imaging. Trace element chemistry was then used to confirm this classification. Altered zircon commonly appears as white or dark grey in CL. These altered grains are also enriched in non-formula elements, e.g., Sr, $\mathrm{Fe}$, and light rare earth elements (LREE) [59]. In the study area, altered zircons are enriched in Fe, $\mathrm{Sr}$, and LREE (mostly La). Zircon grains defined as pristine fulfill the following criteria: (1) zircon are homogenously grey (light or dark) in CL, with or without oscillatory or banded zoning; (2) fracture, visible inclusion, and porosity are absent, except for the one that can be avoided during LA-ICP-MS analysis; and (3) Sr and La contents are low, with $\mathrm{Sr}<6 \mathrm{ppm}$ and La $<1$ (Figure 3a,b), and the LREE content has to be under 100 ppm.

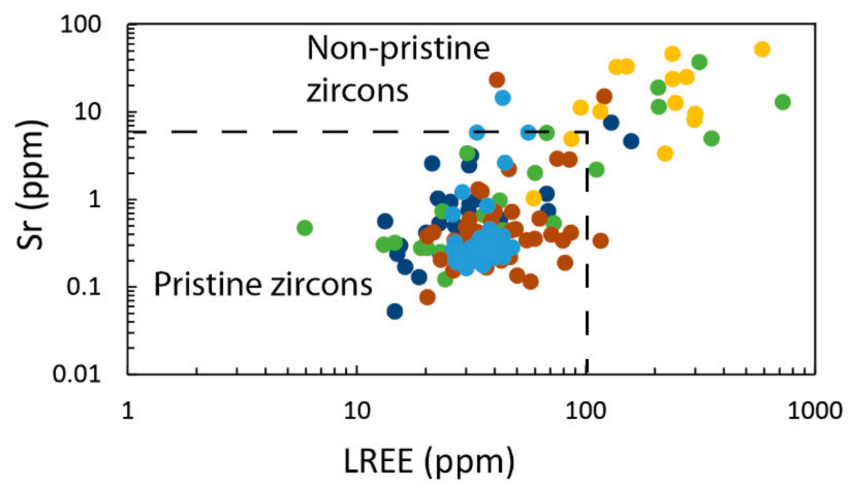

(a)

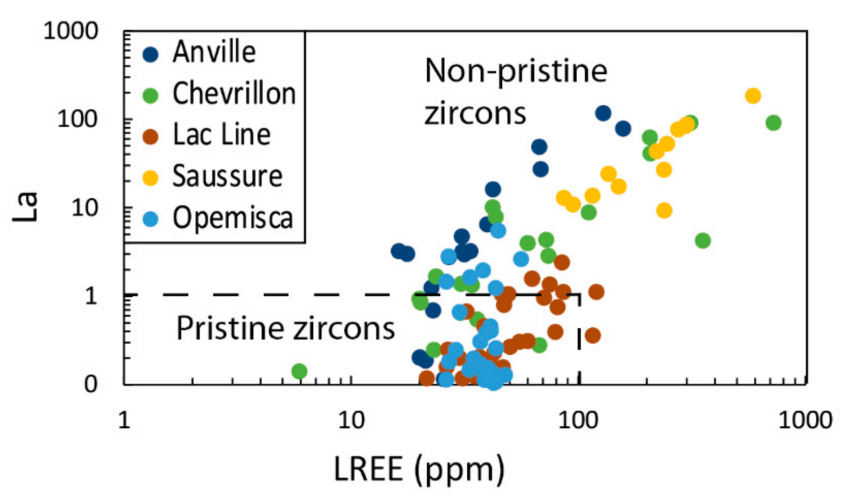

(b)

Figure 3. Discrimination diagrams for magmatic (pristine) and non-pristine zircons (metamict zircons and/or zircons modified by secondary processes), showing the (a) Sr vs. light rare earth elements (LREE); and (b) La vs. LREE contents of zircon. Black dashed lines locate the pristine zircon and non-pristine zircon fields. La data are normalized to chondrite [60]. 


\subsection{Uranium- $\mathrm{Th}-\mathrm{Pb}$ Isotopic Ratios}

Uranium- $\mathrm{Th}-\mathrm{Pb}$ isotopic ratios and trace element analyses were performed on $\sim 50$ zircons from the Anville, Saussure and Chevrillon intrusions, using split stream LA-MC-Q-ICP-MS at the Mineral Exploration Research Centre-Isotope Geochemistry Laboratory (MERC-IGL) at Laurentian University. The details of analytical setup, reference materials used, and data quality control are described in Supplementary Material Table S1. Data quality was monitored using the reference materials NIST 610, NIST 612, OG1, OGC, and 91500. The results are in good agreement with expected values (Supplementary Material Table S3).

\subsection{Data Processing}

Mineral chemistry data were processed to obtain intensive parameters for the studied intrusions, including temperature and oxidation state (oxygen fugacity- $f \mathrm{O}_{2}$ ). Temperatures were obtained using the Ti-in-zircon thermometer of Ferry and Watson [61]. To apply this method, data from the LabMaTer and MERC-IGL were used and bulk rock chemistry was assumed to be representative of melt composition and was used to calculate the FM parameter [61]. Furthermore, the activities of $\mathrm{SiO}_{2}$ and $\mathrm{TiO}_{2}\left(\alpha \mathrm{TiO}_{2}\right.$ and $\left.\alpha \mathrm{SiO}_{2}\right)$ were estimated as follows. The bulk of the studied intrusions contains primary magmatic quartz and the $\alpha \mathrm{SiO}_{2}$ parameter is, thus, 1 . The main Ti-bearing mineral is titanite and $\alpha \mathrm{TiO}_{2}$ is $<1$. The $\alpha \mathrm{TiO}_{2}$ parameter is estimated with the method of Hayden and Watson [62], using a temperature of $850{ }^{\circ} \mathrm{C}$ and a FM parameter of $2.65,3.19,2.98$, and 1.96 for the Saussure, Opémisca, Chevrillon, and Anville intrusions, respectively. The $\alpha \mathrm{TiO}_{2}$ parameter is $0.3,0.5,0.6$, and 0.7 for the Saussure, Opémisca, Chevrillon, and Anville intrusions, respectively. The FM parameter could not be calculated for the altered rocks of $\mathrm{Lac}$ Line intrusion and $\alpha \mathrm{TiO}_{2}$ is assumed to be 0.6 for this intrusion, which is a reasonable value for felsic magmas $[62,63]$.

Four methods based on the chemistry of different minerals were used to determine the oxidation states of the studied magmas and to evaluate which method is most suitable for the estimation of the $f \mathrm{O}_{2}$ of these Archean magmas. Redox conditions during crystallization were estimated from the trace element contents of apatite and zircon. These methods were only applied to pristine grains to constrain the redox conditions of the parental melt. Cerium and Eu anomalies in apatite are dependent on $f \mathrm{O}_{2}$, bulk rock composition, temperature, pressure, as well as co-existing mineral assemblage (e.g., plagioclase fractionation modifies $\mathrm{Eu} / \mathrm{Eu}^{*}$ ) [64-66]. For apatite, $\mathrm{Ce}$ and $\mathrm{Eu}$ anomalies were displayed and interpreted using the binary diagram of Azadbakht [67].

In zircon, oxidation state was estimated using the $\mathrm{Ce} / \mathrm{Ce}^{*}$ vs. $\mathrm{Eu} / \mathrm{Eu}^{*}$ oxybarometer of Loader and collaborators [51], the $\left(\frac{C e}{C e *}\right)_{C H U R}$ oxybarometer of Trail and collaborators [68,69], and the REE-independent $\left[\frac{X_{\mathrm{C}^{4+t}}^{\mathrm{Melt}}}{X_{\mathrm{C}^{3+}}^{\text {Met }}}\right]$ oxybarometer of Smythe and Brenan $[70,71]$. These methods are based on the incorporation of Ce in zircon and on the lattice strain model [72].

The $\left(\frac{C e}{C e^{*}}\right)_{C H U R}$ oxybarometer (Equation (1)) is a redox-sensitive method used to determine the oxidation state of magmas based on the partition coefficients ( $\left.D^{\text {zircon/chondrite }}\right)$ of $\mathrm{Ce}$, La, and $\operatorname{Pr}$ for zircon $[68,69,73]$.

$$
\left(\frac{C e}{C e^{*}}\right)_{C H U R}=\frac{D_{C e}^{z i r c o n / \text { chondrite }}}{\sqrt{\left(D_{L a}^{z i r c o n / c h o n d r i t e} \times D_{P r}^{z i r c o n / c h o n d r i t e ~}\right.}}
$$

The equation was put forward by Trail and collaborators and was further simplified by Zou and collaborators [68,69,72] Equation (2).

$$
\left(\frac{C e}{C e^{*}}\right)_{\text {CHUR }}=\frac{\left(\frac{C e}{\sqrt{(L a \times P r)}}\right)_{z i r c o n}}{4.17}
$$


Using this oxybarometer Equation (2), oxygen fugacity is then calculated after Trail and collaborators [69] Equation (3).

$$
\ln \left(\frac{C e}{C e^{*}}\right)_{C H U R}=(0.1156 \pm 0.0050) \times \ln \left(\mathrm{fO}_{2}\right)+\frac{(13860 \pm 708)}{T(K)}-(6.125 \pm 0.484)
$$

with $\mathrm{K}$ the temperature in Kelvin.

The $\mathrm{Ce} / \mathrm{Ce}^{*}$ vs. $\mathrm{Eu} / \mathrm{Eu}^{*}$ oxybarometer is based on the REE content of zircon but due to low concentration of La and Pr in zircon (usually $<0.1 \mathrm{ppm}$ ) and the abundance of LREE-rich micro-inclusions such as apatite or titanite [51] that can lead to a misestimation of the $f \mathrm{O}_{2}$ parameter, the method was reformulated Equation (4) [51].

$$
C e^{*}=\frac{N d_{N}^{2}}{S m_{N}}
$$

with $\mathrm{N}$ the normalization to the chondrite [60].

Smythe and Brenan $[70,71]$ formulated a REE-independent $\left[\frac{X_{C 4^{+}}^{\text {Melt }}}{X_{C^{3+}}^{M e l+}}\right]$ oxybarometer (6) based on the partition coefficients of Ce in zircon ( $D^{\text {zircon/chondrite }}$ ) Equations (5) and (6).

$\ln \left[\frac{\mathrm{X}_{\mathrm{Ce}}^{\mathrm{Melt}}}{\mathrm{X}_{\mathrm{C} e^{3+}}^{\mathrm{Melt}}}\right]=\frac{1}{4} \ln \left(\mathrm{fO}_{2}\right)+\frac{13136( \pm 591)}{T}-2.064( \pm 0.011) \frac{\mathrm{NBO}}{t}-8.878( \pm 0.112) \times \mathrm{H}_{2} \mathrm{O}-8.955( \pm 0.091)$

where $\mathrm{T}$ is the temperature in kelvin calculated using a Ti-in-zircon thermometer, $\mathrm{H}_{2} \mathrm{O}$ is the water content of the melt estimated using the empirical amphibole formulation $[74,75]$ and $\mathrm{NBO} / \mathrm{t}$ is the proportion of non-bridging oxygen where $\mathrm{NBO}=2 \mathrm{O}-4 \mathrm{~T}$ and $t=\mathrm{Si}+\mathrm{Ti}+\mathrm{Al}+\mathrm{P}$ (in atomic percent), as $\mathrm{Al}<\mathrm{Na}+\mathrm{K}+2 \mathrm{Ca}+2 \mathrm{Mg}$ [76]. Moreover, the REE-independent $\left[\frac{\mathrm{X}_{\mathrm{Ce}+4}^{\mathrm{Melt}}}{X_{\mathrm{C} e^{3+}}^{\mathrm{Melt}}}\right]$ oxybarometer is estimated

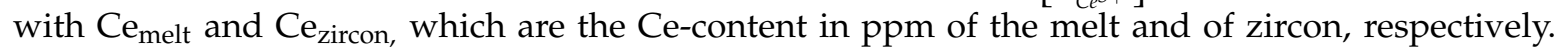
Equations (5) and (6):

$$
\left[\frac{X_{C e^{++}}^{M e l t}}{X_{C e^{3+}}^{M e l t}}\right]=\frac{\Sigma C e_{\text {Zircon }}-\Sigma C e_{\text {melt }} \times D_{C e^{3+}}^{z i r c o n / \text { whole rock }}}{\Sigma C e_{\text {Melt }} \times D_{C e^{4+}}^{z i r c o n / \text { whole rock }}-\Sigma C e_{\text {Zircon }}} \times 1.04877
$$

where the $\mathrm{Ce}_{\text {melt }}$ parameter is estimated by assuming that whole rock analyses are representative of melt composition.

\section{Results}

\subsection{Whole Rock Geochemistry}

The studied intrusions $(\mathrm{n}=38)$ are intermediate to felsic, with Si contents ranging from 62 to 77 wt. $\% \mathrm{SiO}_{2}$ (Table 3, Figure 4a). Moreover, they tend to be peraluminous (Figure $4 \mathrm{~b}$ ) alkaline to subalkaline granite, syenite, and monzonite according to their $\mathrm{Si}$ - and $\mathrm{Na}$ and $\mathrm{K}$-contents (Figure 4). The alkaline Saussure intrusion is the most enriched in $\mathrm{Na}$ and $\mathrm{K}$ (Figure 4a). 
Table 3. Whole-rock chemistry of the sampled intrusions.

\begin{tabular}{|c|c|c|c|c|c|c|}
\hline \multirow{2}{*}{$\begin{array}{c}\text { Intrusions } \\
\text { Elements }\end{array}$} & \multicolumn{2}{|c|}{ Saussure } & \multirow{2}{*}{$\begin{array}{c}\text { Opémisca } \\
\text { U139 }\end{array}$} & \multirow{2}{*}{$\begin{array}{c}\text { Lac Line } \\
\text { LL01 }\end{array}$} & \multirow{2}{*}{$\begin{array}{c}\text { Chevrillon } \\
\text { CHV01 }\end{array}$} & \multirow{2}{*}{$\begin{array}{c}\text { Anville } \\
\text { U140 }\end{array}$} \\
\hline & S101 & S401 & & & & \\
\hline $\begin{array}{c}\mathrm{SiO}_{2} \\
\text { (wt.\%) }\end{array}$ & 67.40 & 63.3 & 62.50 & 63.10 & 64.20 & 77.00 \\
\hline $\mathrm{Al}_{2} \mathrm{O}_{3}$ & 15.55 & 17.3 & 17.10 & 17.60 & 16.00 & 12.30 \\
\hline $\mathrm{FeO}$ & 1.38 & 1.26 & 1.47 & 1.64 & 1.50 & 1.45 \\
\hline $\mathrm{Fe}_{2} \mathrm{O}_{3}$ & 1.66 & 1.84 & 2.29 & 2.15 & 1.94 & 1.12 \\
\hline $\mathrm{CaO}$ & 1.96 & 1.82 & 3.44 & 4.28 & 3.21 & 1.30 \\
\hline $\mathrm{MgO}$ & 1.24 & 0.86 & 2.37 & 2.19 & 1.78 & 0.22 \\
\hline $\mathrm{Na}_{2} \mathrm{O}$ & 5.04 & 5.91 & 6.32 & 5.17 & 5.03 & 4.03 \\
\hline $\mathrm{K}_{2} \mathrm{O}$ & 4.15 & 5.76 & 2.44 & 1.03 & 2.99 & 2.29 \\
\hline $\mathrm{TiO}_{2}$ & 0.40 & 0.35 & 0.34 & 0.32 & 0.48 & 0.15 \\
\hline $\mathrm{MnO}$ & 0.04 & 0.05 & 0.06 & 0.06 & 0.04 & 0.04 \\
\hline $\mathrm{P}_{2} \mathrm{O}_{5}$ & 0.29 & 0.21 & 0.19 & 0.14 & 0.23 & 0.02 \\
\hline $\mathrm{BaO}$ & 0.20 & 0.150 & 0.10 & 0.06 & 0.18 & 0.05 \\
\hline LOI & 0.31 & 0.21 & 0.56 & 1.92 & 0.60 & 0.44 \\
\hline TOTAL & 99.62 & 99.02 & 99.18 & 99.79 & 98.18 & 100.41 \\
\hline $\mathrm{C}(\mathrm{ppm})$ & 0.01 & 0.01 & 0.01 & 0.03 & 0.00 & 0.01 \\
\hline $\mathrm{Ce}$ & 152.00 & 170.5 & 54.80 & 75.00 & 101.00 & 72.70 \\
\hline $\mathrm{Cr}$ & 40.00 & 20 & 110.00 & 40.00 & 60.00 & 30.00 \\
\hline Cs & 4.14 & 0.46 & 0.35 & 0.50 & 2.46 & 0.38 \\
\hline Dy & 1.72 & 3.37 & 2.02 & 1.23 & 1.81 & 5.61 \\
\hline $\mathrm{Er}$ & 0.60 & 1.54 & 1.03 & 0.59 & 0.80 & 3.78 \\
\hline $\mathrm{Eu}$ & 1.88 & 2.59 & 1.02 & 1.04 & 1.63 & 0.91 \\
\hline $\mathrm{Ga}$ & 22.10 & 20.9 & 20.10 & 20.90 & 24.10 & 16.20 \\
\hline $\mathrm{Gd}$ & 4.45 & 6.88 & 2.97 & 2.41 & 4.21 & 5.58 \\
\hline Hf & 5.80 & 5.7 & 4.20 & 2.50 & 4.60 & 5.90 \\
\hline Ho & 0.31 & 0.56 & 0.39 & 0.22 & 0.29 & 1.18 \\
\hline $\mathrm{La}$ & 79.80 & 77.8 & 26.90 & 36.00 & 51.00 & 36.80 \\
\hline $\mathrm{Lu}$ & 0.05 & 0.12 & 0.15 & 0.08 & 0.07 & 0.58 \\
\hline $\mathrm{Nb}$ & 9.90 & 15.2 & 6.90 & 2.80 & 5.40 & 10.30 \\
\hline $\mathrm{Nd}$ & 62.20 & 73.7 & 26.50 & 31.90 & 47.60 & 28.80 \\
\hline $\operatorname{Pr}$ & 17.00 & 19.95 & 6.63 & 8.36 & 12.50 & 7.83 \\
\hline $\mathrm{Rb}$ & 124.00 & 110 & 42.90 & 24.20 & 75.30 & 61.70 \\
\hline Sm & 8.48 & 10.95 & 4.07 & 4.08 & 7.47 & 6.25 \\
\hline Sn & 1.00 & 1 & 1.00 & 1.00 & 2.00 & 3.00 \\
\hline $\mathrm{Sr}$ & 1240.00 & 1285 & 1165.00 & 1140.00 & 1410.00 & 79.20 \\
\hline $\mathrm{Ta}$ & 0.70 & 0.9 & 0.50 & 0.20 & 0.50 & 1.30 \\
\hline $\mathrm{Tb}$ & 0.42 & 0.84 & 0.38 & 0.29 & 0.44 & 0.88 \\
\hline $\mathrm{Th}$ & 14.70 & 4.62 & 3.03 & 4.71 & 6.12 & 9.58 \\
\hline $\mathrm{Tm}$ & 0.07 & 0.19 & 0.17 & 0.08 & 0.10 & 0.57 \\
\hline $\mathrm{U}$ & 1.72 & 0.96 & 0.55 & 0.67 & 1.06 & 1.82 \\
\hline $\mathrm{V}$ & 38.00 & 47 & 60.00 & 59.00 & 67.00 & 7.00 \\
\hline $\mathrm{Y}$ & 8.70 & 16.2 & 10.60 & 6.40 & 8.40 & 35.90 \\
\hline $\mathrm{Yb}$ & 0.48 & 1.06 & 1.14 & 0.54 & 0.55 & 3.95 \\
\hline $\mathrm{Zr}$ & 247.00 & 299 & 173.00 & 108.00 & 170.00 & 200.00 \\
\hline
\end{tabular}




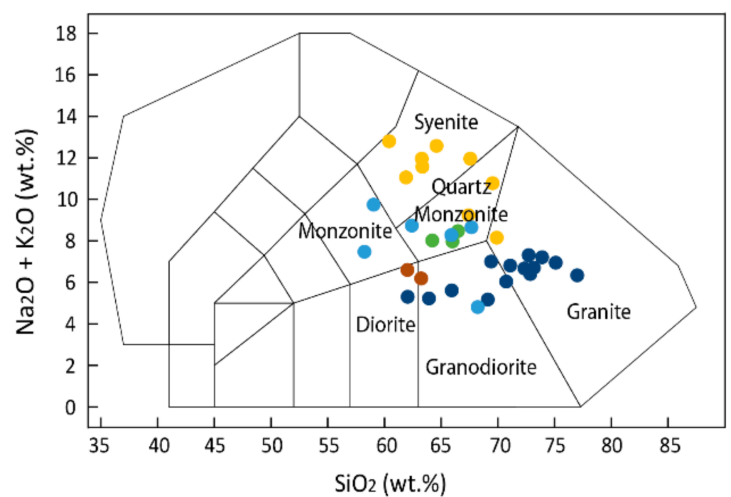

(a)

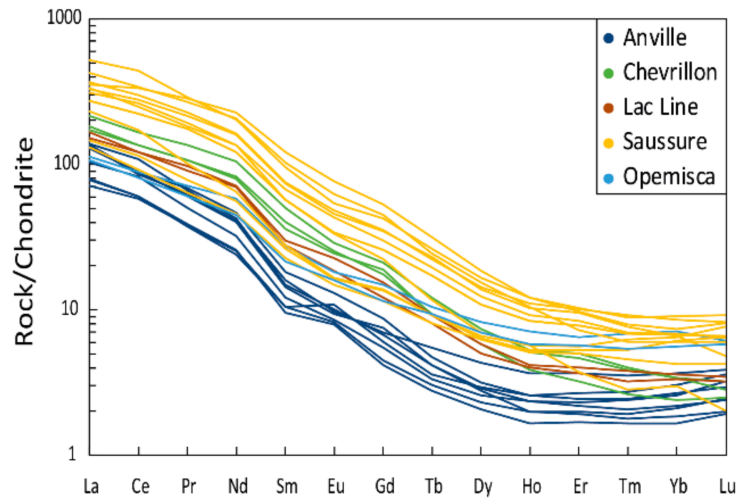

(c)

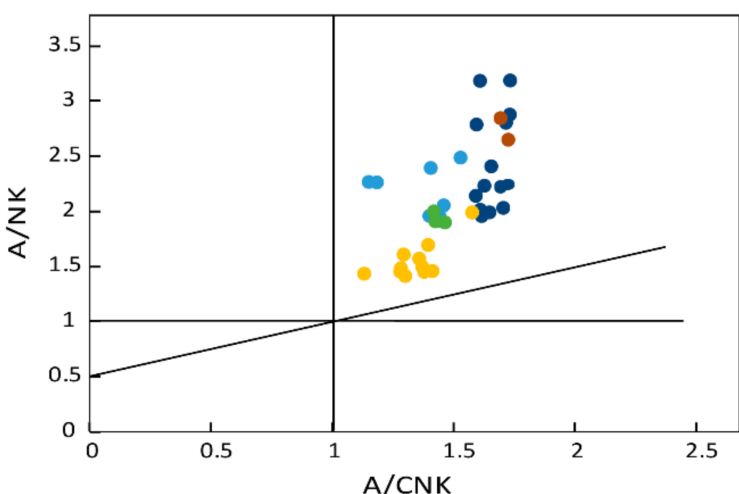

(b)

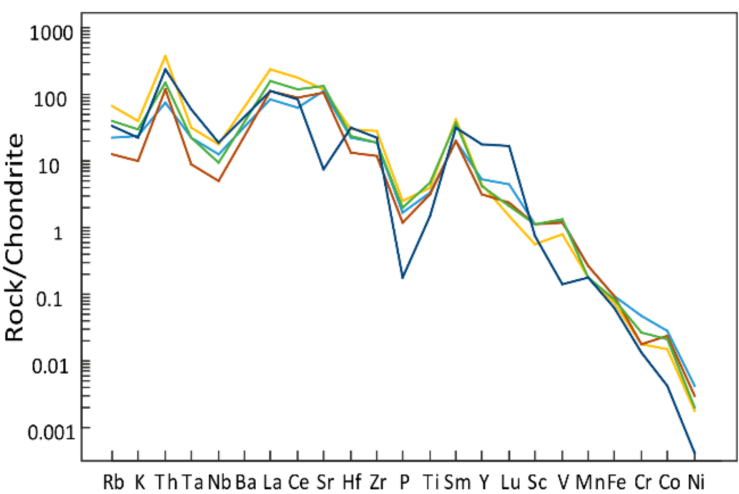

(d)

Figure 4. Whole rock $(n=38)$ analyses displayed on the $(a)$ the total alkali silicate (TAS) diagram for intrusive rocks [77,78]; (b) A/NK vs. A/CNK diagram with $\mathrm{A}, \mathrm{N}, \mathrm{K}$ and $\mathrm{C}$ standing for $\mathrm{Al}, \mathrm{Na}$, $\mathrm{K}$, and $\mathrm{Ca}$, respectively [79], (c) chondrite normalized rare earth elements (REE) pattern [60]; and (d) multi-element diagrams for immobile elements displaying data acquired during this study.

Except for the Anville intrusion, the intrusions display similar trace element contents. The bulk of the studied intrusions display negative $\mathrm{Ta}, \mathrm{Nb}$, Ti, and $\mathrm{Rb}$ anomalies (Figure 4d). The Anville intrusion also displays strong negative $\mathrm{Sr}, \mathrm{V}$, and $\mathrm{P}$ anomalies and flat Eu anomaly (Figure 4c).

The bulk of the studied intrusions displays a strong fractionation of the LREE over the heavy REE (HREE) on the chondrite-normalized REE patterns (Figure $4 \mathrm{c}$ ), with $(\mathrm{La} / \mathrm{Yb})_{\mathrm{N}}$ ratio of 15 to 30 for the Anville and Opémisca intrusions, and 40 to 70 for the Chevrillon, Lac Line, and Saussure intrusions (Figure 4c). Three samples from the Anville intrusion display a positive Eu anomaly possibly due to local plagioclase accumulation, while the other intrusions show no to slight positive Eu anomalies. Moreover, the syenite sample from the Saussure intrusion contains more REE (up to 500-ppm $\sum$ REE for Saussure) than rocks from the other intrusions (from 80 to 200-ppm $\sum$ REE).

\subsection{Petrography}

The studied samples are mostly composed of feldspar (plagioclase and alkali feldspar), quartz, biotite, and green hornblende (Table 2). Except for the rocks of the Anville intrusion, which are dominated by quartz, the studied intrusions are mostly made of K-feldspar and plagioclase. Plagioclase from each sample is recrystallized, with overgrowth texture and saussuritization in the core. The Saussure and Chevrillon intrusions contain K-feldspar phenocrysts. Accessory phases are apatite, zircon, epidote, titanite, magnetite, and pyrite. In the Lac Line and Anville intrusions, amphibole and biotite have been replaced by chlorite, actinolite, and carbonate. Amphiboles are observed in the samples from the Chevrillon, Opémisca, and Saussure intrusions. Amphibole grains are mostly subhedral to euhedral and are in contact with feldspar. Some amphiboles from the Opémisca intrusion 
are resorbed. Moreover, some amphiboles from the Saussure intrusion are altered and/or partly replaced by accessory minerals, such as albite, chlorite and, epidote. Most inclusions observed in amphibole are apatite, magnetite, and titanite.

Apatite is generally observed as inclusions in amphibole and feldspar and is generally abundant, except in the Anville intrusion. Apatite is euhedral to subhedral and grain-size varies from coarse-grained (up to $1 \mathrm{~mm}$ long in the Saussure intrusion) to finer-grained, i.e., $<200 \mu \mathrm{m}$ in the Opémisca and Chevrillon Plutons, $<100 \mu \mathrm{m}$ (Lac Line intrusion) and $<30 \mu \mathrm{m}$ (Anville intrusion). Apatite displays oscillatory zoning (Figure 5a), with resorbed cores and overgrowth textures that indicate complex crystallization history. Oscillatory zoning is typical for minerals with a magmatic origin [80,81]. Some apatites from the Opémisca, Anville, Saussure, and Chevrillon intrusions are more homogeneous, indicating more continuous crystallization, and/or less recrystallization. Cracks are common in the studied apatite and most grains from the hydrothermally altered Lac Line intrusion and the Opémisca intrusion are porous, unzoned, and display corroded rims.
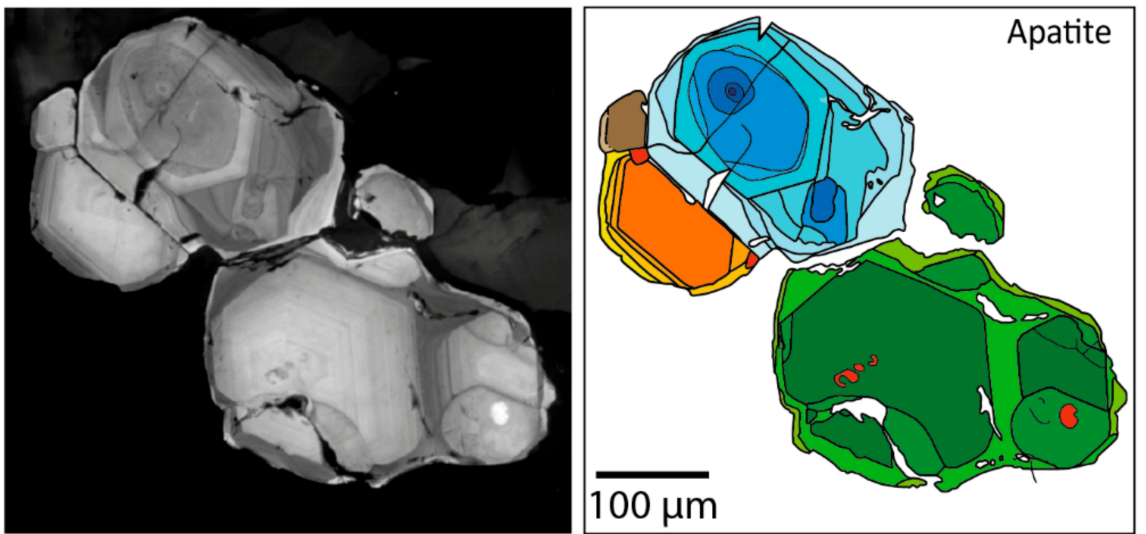

(a)
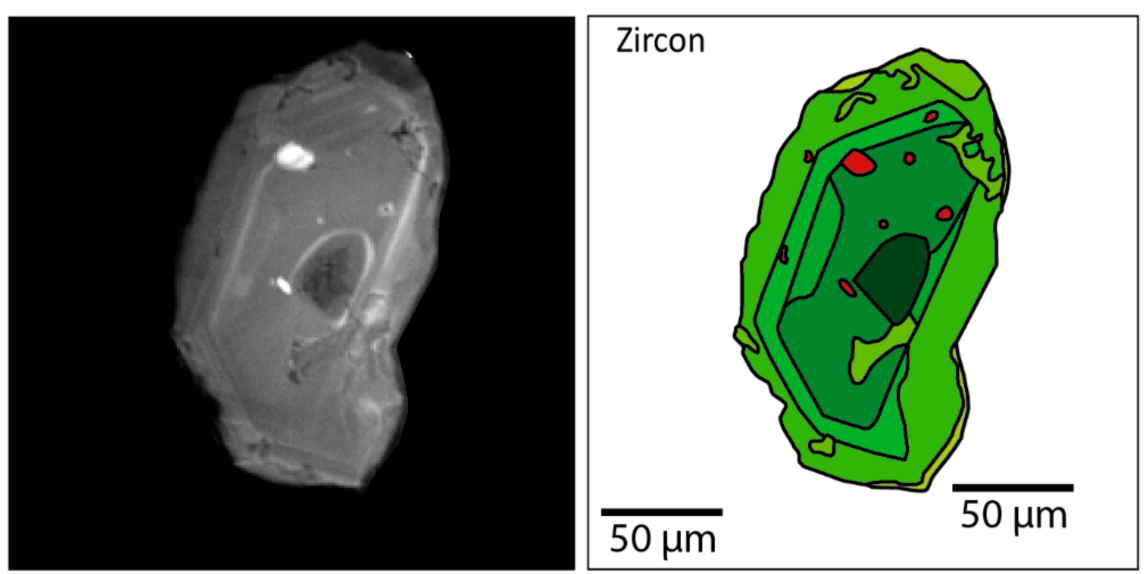
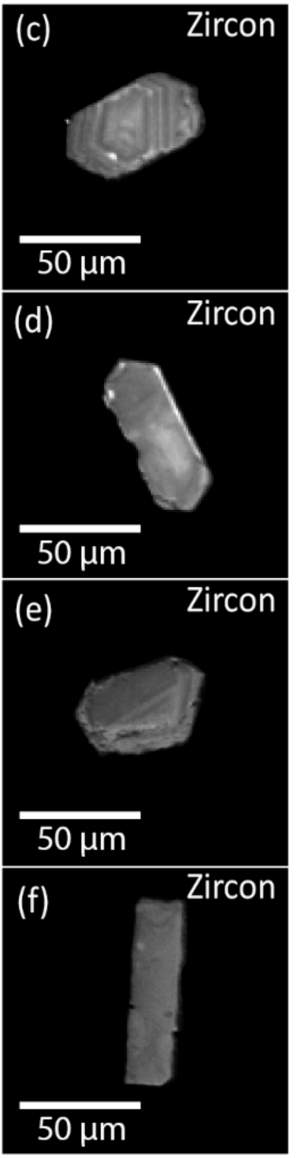

(b)

Figure 5. Cathodoluminescence imagery and drawing of zoned (a) apatite, and (b) zircon from the Anville, (c) Chevrillon, (d) Opémisca, (e) Saussure, and (f) Lac Line intrusions. Red color is used to highlight inclusions in apatite and zircon, distinct colors are used to distinguish grains, and shade of colors correspond to growth stages.

Zircons are translucent to light brown in natural light and are generally subhedral to euhedral. Grain size varies between 100 and $150 \mu \mathrm{m}$ in most samples, except for some $>200 \mu \mathrm{m}$ long grains observed in the Opémisca, Lac Line, and Anville intrusions. In the bulk of samples, part of the zircon grains display cracks and corroded rims. Multiple concentric growth zoning and resorbed cores are observed (Figure $5 b-f)$, which is common for magmatic zircons. Zircon displays tabular (1:1 aspect 
ratio for the Saussure and Anville intrusions-Figure 5b,e) to elongated prismatic morphology (1:2 to 1:4 aspect ratio for the Anville, Opémisca, Lac Line, and Chevrillon intrusions, Figure $5 \mathrm{c}, \mathrm{d}, \mathrm{f})$. Zircons from the Anville, Saussure, and Chevrillon intrusions are strongly altered and metamict. The most common inclusion observed in zircon is tabular apatite.

According to the calculation of the structural formula [82], amphiboles are calcic ${ }^{\mathrm{B}}(\mathrm{Ca} /(\mathrm{Ca}+\mathrm{Na}) \geq 0.75 \mathrm{apfu})$ with low-Al content $(\leq 10 \mathrm{wt} . \% \mathrm{Al})$. In the bulk of intrusions, amphiboles are all magnesio-hornblende, tremolite, and pargasite (Supplementary Material Table S2). Amphiboles from the Chevrillon Pluton are the most enriched in $\mathrm{Al}, \mathrm{Fe}$, and $\mathrm{K}$, and these from the Opémisca intrusion are the most enriched in $\mathrm{Mg}$ and $\mathrm{Cl}$ (Table 4).

Apatites are fluorapatites, containing 2.6 to $4.6 \mathrm{wt} . \% \mathrm{~F}$, and $<0.03 \mathrm{wt} . \% \mathrm{Cl}$ except for the apatites from the Lac Line intrusion that contain 0.05 to $0.1 \mathrm{wt}$.\% Cl (Supplementary Material Table S1). Fluorapatites are common in felsic magma [83]. Major constituents are close to stoichiometric values with 37.1 to $39.5 \mathrm{wt} . \% \mathrm{Ca}$ and 17.2 to $19.1 \mathrm{wt}$ \% P. Most apatites are S-poor, with $<0.08 \mathrm{wt} . \%$ S, except for the apatites of the Lac Line and Saussure intrusions that contain $>0.1$ to $0.2 \mathrm{wt} . \% \mathrm{~S}$. Silica and Na generally vary from 0.01 to $0.3 \mathrm{wt} . \%$ for all the samples. Titanium, $\mathrm{Al}, \mathrm{K}, \mathrm{Mg}$, and $\mathrm{Mn}$-contents are generally $<0.1 \mathrm{wt} . \%$ and iron is generally $<0.1 \mathrm{wt} . \%$ Fe to up to $0.5 \mathrm{wt} . \%$ Fe in the bulk of the analyzed apatites (Table 4).

The Sr and Y contents of apatite range from $60 \mathrm{ppm}$ to $1 \mathrm{wt} . \% \mathrm{Sr}$ and from 70 to $5000 \mathrm{ppm}$ Y. Moreover, three main types of apatite (Groups 1, 2, and 3) are distinguished on the basis of their chondrite-normalized REE patterns (Figure 6). Group 1 apatite is observed in the Anville intrusion and is characterized by limited fractionation of the LREE over the HREE on their chondrite-normalized REE patterns $\left(\mathrm{La} / \mathrm{Yb}_{\mathrm{N}}\right.$ ratio of 0 to 2), with convex-upward LREE profile and strong negative Eu anomaly. Group 2 apatite is from the Lac Line intrusion and is characterized by weak fractionation of the LREE over the HREE on their chondrite-normalized REE patterns, $\left(\mathrm{La} / \mathrm{Yb}_{\mathrm{N}}\right.$ ratio of 16 to 50$)$ and a small negative Eu anomaly. Group 3 apatite is from the Opémisca, Chevrillon, and Saussure intrusions, and is characterized by strong fractionation of the LREE over the HREE on their chondrite-normalized REE patterns ( $\mathrm{La} / \mathrm{Yb}_{\mathrm{N}}$ ratio of 30 to 250 ) and no significant Eu anomaly. Apatite from the Saussure, Lac Line, and Opémisca intrusions is the LREE richest with 10,000 to 30,000 ppm $\sum$ LREE and up to $50,000 \mathrm{ppm}$ for some apatites from the Saussure intrusion.

The $\mathrm{Zr}$-content of zircon is close to stoichiometric value (58 wt.\% $\mathrm{ZrO}_{2}$ ), except near cracks and apatite inclusions, where it can range from 53 to $61 \mathrm{wt} . \% \mathrm{ZrO}_{2}$ (Supplementary Material Table S1). Hafnium, which is the most abundant trace element in zircon, has a concentration of 0.70 to $1.40 \mathrm{wt} . \%$ $\mathrm{HfO}_{2}$. Trace elements such as $\mathrm{P}$ and Ti range from a few to thousands of ppm and from below the limit of detection (LOD) to hundreds of ppm, respectively (Table 5). Yttrium contents range from 1000 to 10,000 ppm Y. Zircon from the Anville intrusion contains more Y (1000s of ppm Y) than zircon from other intrusions ( $<1000 \mathrm{ppm}$ Y). Tantalum in zircon is between 0.05 and $1 \mathrm{ppm}$ for the bulk of intrusions, except for the Anville intrusion where zircon contains 1 to $3.5 \mathrm{ppm}$ Ta. Moreover, Ta is positively correlated with $\mathrm{Nb}$ (LOD to $5 \mathrm{ppm} \mathrm{Nb}$ for the bulk of intrusions and up to $15 \mathrm{ppm}$ for the Anville intrusion). 
Table 4. Trace elements and REE composition of apatite from the studied intrusions.

\begin{tabular}{|c|c|c|c|c|c|c|c|c|c|c|c|c|c|c|c|}
\hline \multirow{2}{*}{$\begin{array}{l}\text { Intrusions } \\
\text { Elements }\end{array}$} & \multicolumn{3}{|c|}{ Anville } & \multicolumn{3}{|c|}{ Chevrillon } & \multicolumn{3}{|c|}{ Lac Line } & \multicolumn{3}{|c|}{ Opémisca } & \multicolumn{3}{|c|}{ Saussure } \\
\hline & Min & Mean & Max & Min & Mean & Max & Min & Mean & Max & Min & Mean & Max & Min & Mean & Max \\
\hline $\mathrm{Li}$ & ND & 25.8 & 152.4 & ND * & 3.6 & 20.1 & ND & 4.2 & 18.9 & ND & 3.2 & 21.3 & 1.0 & 5.0 & 16.6 \\
\hline $\mathrm{Na}$ & 414.2 & 876.8 & 1766.6 & 222.7 & 2432.9 & $29,952.8$ & 287.4 & 783.4 & 1816.4 & 194.7 & 816.8 & 2050.3 & 389.2 & 5195.3 & $117,998.2$ \\
\hline $\mathrm{Mg}$ & 14.2 & 3617.9 & $26,431.3$ & 13.0 & 1053.0 & 8621.2 & 10.2 & 939.8 & $11,077.4$ & 13.7 & 871.0 & $13,092.0$ & 4.2 & 890.1 & $20,498.0$ \\
\hline $\mathrm{Al}$ & 1006.1 & $17,594.6$ & $108,042.4$ & 32.4 & 3358.0 & $40,388.3$ & 222.0 & 1746.5 & $11,838.2$ & 36.8 & 973.2 & 8241.2 & 60.6 & 4860.8 & $133,241.2$ \\
\hline $\mathrm{Si}$ & 2500.4 & $25,923.9$ & $117,541.2$ & ND & 8389.0 & $106,053.2$ & ND & 3241.3 & $38,686.5$ & ND & 2815.7 & $19,774.3$ & 781.4 & $19,362.5$ & $383,624.1$ \\
\hline $\mathrm{S}$ & ND & 263.6 & 1038.6 & ND & 464.9 & 916.6 & 298.6 & 1371.4 & 2384.7 & 133.7 & 540.2 & 959.2 & 361.6 & 974.1 & 1645.5 \\
\hline $\mathrm{Cl}$ & ND & 232.7 & 592.3 & ND & 180.4 & 1013.2 & 124.0 & 687.4 & 1064.2 & ND & 112.1 & 362.5 & 31.6 & 115.7 & 411.6 \\
\hline $\mathrm{K}$ & 3.1 & 129.4 & 369.2 & ND & 151.7 & 990.5 & ND & 38.8 & 254.5 & 0.5 & 255.6 & 2429.0 & ND & 72.4 & 994.1 \\
\hline $\mathrm{Ti}$ & ND & 1351.4 & $10,356.4$ & ND & 333.7 & 6667.4 & 1.3 & 27.7 & 535.6 & 0.2 & 164.2 & 3149.2 & 0.1 & 22.8 & 554.1 \\
\hline $\mathrm{V}$ & 0.2 & 12.6 & 58.6 & 3.1 & 14.8 & 90.2 & 5.0 & 17.9 & 44.6 & 4.9 & 38.2 & 483.0 & 5.3 & 27.7 & 264.3 \\
\hline $\mathrm{Mn}$ & 336.0 & 1173.6 & 6223.5 & 158.1 & 308.6 & 711.7 & 303.3 & 553.5 & 777.0 & 213.3 & 327.7 & 741.0 & 124.2 & 317.7 & 2723.0 \\
\hline $\mathrm{Fe}$ & 108.8 & 9119.4 & $63,402.0$ & 56.2 & 1217.8 & $10,177.3$ & 855.7 & 1590.5 & 7864.7 & 43.0 & 4714.6 & $95,786.4$ & 49.8 & 624.3 & $14,325.2$ \\
\hline $\mathrm{Rb}$ & ND & 2.6 & 28.9 & ND & 1.4 & 16.2 & ND & 0.1 & 2.6 & ND & 0.7 & 9.3 & ND & 2.1 & 17.9 \\
\hline $\mathrm{Sr}$ & 55.2 & 73.5 & 118.9 & 887.7 & 1116.3 & 1779.2 & 338.2 & 398.4 & 506.9 & 830.9 & 905.5 & 986.0 & 723.9 & 1857.6 & 9637.5 \\
\hline $\mathrm{Y}$ & 1382.8 & 2729.3 & 5129.2 & 44.1 & 97.4 & 156.0 & 81.3 & 250.4 & 340.4 & 72.8 & 199.7 & 334.1 & 45.5 & 189.6 & 494.1 \\
\hline $\mathrm{Zr}$ & 0.2 & 158.1 & 1224.9 & 0.2 & 1.7 & 7.1 & 0.1 & 0.9 & 5.2 & 0.2 & 2.0 & 23.7 & 0.3 & 24.4 & 1203.2 \\
\hline Sn & ND & 12.8 & 51.0 & ND & 0.4 & 3.0 & 0.0 & 1.0 & 5.7 & 0.0 & 3.6 & 40.7 & 0.0 & 10.0 & 131.9 \\
\hline $\mathrm{La}$ & 66.0 & 226.5 & 413.6 & 100.3 & 367.2 & 819.4 & 244.7 & 880.5 & 1943.1 & 517.4 & 1374.7 & 2396.7 & 215.5 & 1773.9 & 5257.8 \\
\hline $\mathrm{Ce}$ & 299.7 & 810.0 & 1515.9 & 288.3 & 999.4 & 1981.0 & 737.2 & 2529.5 & 4296.5 & 750.1 & 1997.5 & 3181.5 & 509.4 & 3486.8 & 9158.8 \\
\hline $\operatorname{Pr}$ & 44.0 & 130.6 & 214.7 & 39.7 & 118.1 & 236.0 & 106.0 & 342.1 & 490.0 & 58.5 & 178.6 & 261.6 & 56.1 & 341.9 & 866.4 \\
\hline $\mathrm{Nd}$ & 293.6 & 772.4 & 1317.8 & 187.6 & 504.4 & 972.9 & 482.7 & 1495.0 & 1994.0 & 271.8 & 678.8 & 1070.4 & 211.9 & 1228.4 & 3090.0 \\
\hline $\mathrm{Sm}$ & 106.5 & 275.2 & 477.0 & 27.1 & 73.9 & 137.5 & 67.8 & 218.4 & 281.3 & 28.8 & 90.5 & 160.5 & 20.8 & 151.1 & 446.2 \\
\hline $\mathrm{Eu}$ & 2.3 & 6.4 & 11.8 & 8.2 & 16.9 & 28.0 & 8.5 & 19.0 & 24.8 & 8.1 & 17.9 & 32.4 & 9.9 & 32.1 & 80.8 \\
\hline $\mathrm{Gd}$ & 172.6 & 387.5 & 722.9 & 18.5 & 49.1 & 91.9 & 40.3 & 130.0 & 161.8 & 27.0 & 66.9 & 124.1 & 16.3 & 94.6 & 270.8 \\
\hline $\mathrm{Tb}$ & 29.1 & 60.9 & 114.0 & 1.6 & 4.2 & 8.2 & 3.8 & 12.4 & 15.5 & 2.5 & 6.8 & 12.1 & 1.5 & 8.4 & 24.4 \\
\hline Dy & 192.9 & 399.8 & 736.1 & 6.1 & 18.3 & 31.0 & 15.1 & 55.4 & 70.6 & 10.6 & 35.4 & 61.7 & 6.6 & 37.5 & 107.6 \\
\hline Ho & 45.1 & 88.4 & 156.5 & 1.2 & 3.2 & 5.0 & 2.9 & 9.7 & 13.2 & 2.7 & 6.9 & 11.6 & 1.2 & 6.1 & 16.3 \\
\hline $\mathrm{Er}$ & 133.2 & 250.9 & 461.3 & 2.8 & 7.6 & 11.1 & 7.2 & 22.4 & 32.4 & 7.6 & 19.0 & 30.3 & 3.5 & 14.3 & 38.0 \\
\hline $\mathrm{Tm}$ & 15.7 & 35.8 & 68.1 & 0.4 & 0.9 & 1.6 & 0.9 & 2.7 & 4.9 & 0.8 & 2.5 & 3.6 & 0.4 & 1.7 & 4.6 \\
\hline $\mathrm{Yb}$ & 96.9 & 225.6 & 424.5 & 2.0 & 5.9 & 8.3 & 5.5 & 16.5 & 35.2 & 3.9 & 17.0 & 29.7 & 2.9 & 9.7 & 26.0 \\
\hline $\mathrm{Lu}$ & 12.7 & 33.2 & 63.0 & 0.5 & 1.0 & 1.4 & 0.7 & 2.4 & 6.4 & 1.1 & 2.9 & 5.9 & 0.5 & 1.4 & 3.3 \\
\hline
\end{tabular}




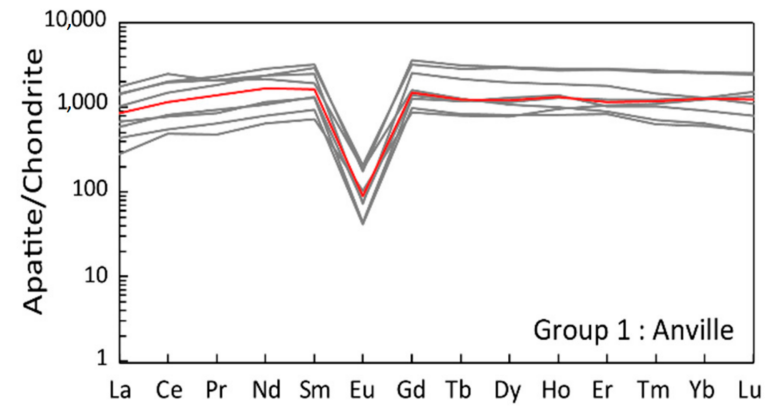

(a)

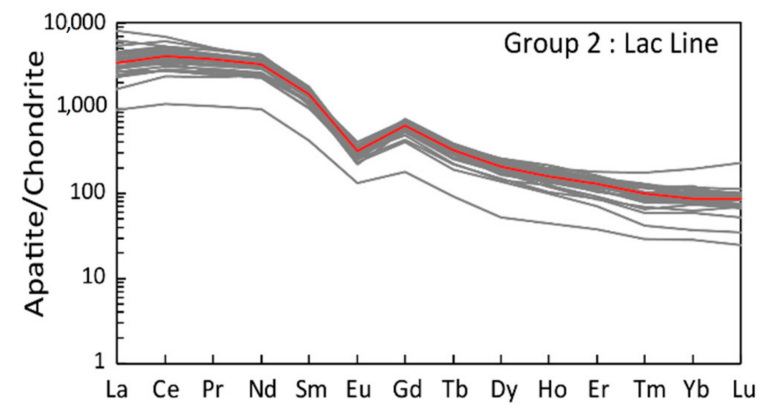

(b)

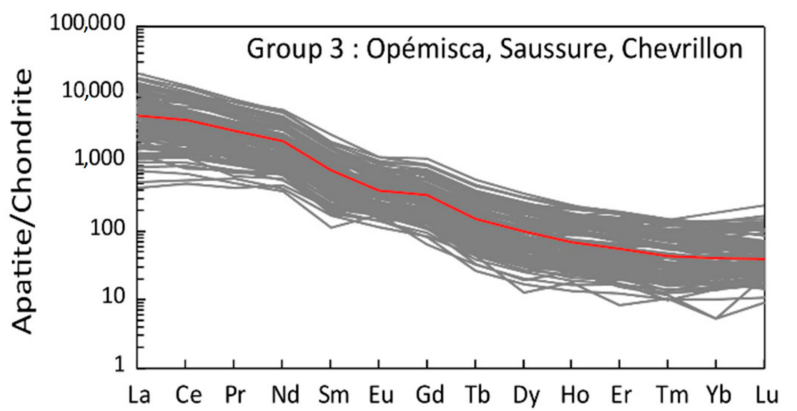

(c)

Figure 6. Chondrite-normalized REE pattern of apatites from the (a) Anville intrusion (Group 1); (b) Lac Line intrusion (Group 2); and (c) Opémisca, Saussure and Chevrillon intrusions (Group 3). Red lines correspond to mean values and data are normalized to chondrite [60].

Except for the non-pristine zircon from the Anville, Saussure, and Chevrillon intrusions that display elevated LREE contents (Figure 7), the bulk of zircon generally displays similar chondrite-normalized REE patterns (Figure 7). On chondrite-normalized REE patterns, LREE are strongly fractionated over HREE and display strong positive Ce anomalies (from $10 \mathrm{~s}$ to $100 \mathrm{~s}$ ) and negative Eu anomalies. Non-pristine grains from the Saussure, Chevrillon and Anville intrusions display chondrite-normalized REE patterns with $\mathrm{La}_{\mathrm{N}}>1$ and LREE enrichment (Table 5). Lanthanum enrichment in pristine zircon points either to La-rich inclusions (apatite), coprecipitation of coeval phases and may locally be a consequence of alteration. The temperatures calculated for the pristine zircon range from $650{ }^{\circ} \mathrm{C}$ to $750{ }^{\circ} \mathrm{C}$, except for few zircons for which temperatures over $800^{\circ} \mathrm{C}$ were obtained (Table 5). 
Table 5. Trace elements and REE composition, as well as chemical parameters of zircon from the studied intrusions. Data of REE are normalized to the chondrite [60].

\begin{tabular}{|c|c|c|c|c|c|c|c|c|c|c|c|c|c|c|c|}
\hline \multirow{2}{*}{$\begin{array}{l}\text { Intrusions } \\
\text { Elements }\end{array}$} & \multicolumn{3}{|c|}{ Anville } & \multicolumn{3}{|c|}{ Chevrillon } & \multicolumn{3}{|c|}{ Lac Line } & \multicolumn{3}{|c|}{ Opémisca } & \multicolumn{3}{|c|}{ Saussure } \\
\hline & Min & Mean & Max & Min & Mean & Max & Min & Mean & Max & Min & Mean & Max & Min & Mean & Max \\
\hline $\mathrm{P}$ & ND & 533.1 & 1432.5 & ND & 775.0 & 5074.8 & 127.5 & 480.2 & 1049.3 & 279.7 & 704.9 & 2080.4 & ND & 407.4 & 2956.2 \\
\hline $\mathrm{Ca}$ & 123.1 & 306.5 & 542.7 & -8.5 & 556.1 & 3128.6 & ND & 43.9 & 856.2 & ND & 60.3 & 298.4 & 209.2 & 777.0 & 1705.9 \\
\hline $\mathrm{Ti}$ & ND & 3.8 & 15.5 & 0.4 & 132.3 & 2726.2 & 0.7 & 6.2 & 20.9 & 2.0 & 6.4 & 53.2 & ND & 29.5 & 150.2 \\
\hline $\mathrm{V}$ & ND & 0.1 & 4.4 & ND & 1.4 & 19.4 & -0.3 & 0.3 & 2.5 & 0.1 & 0.3 & 1.0 & ND & 3.0 & 11.0 \\
\hline $\mathrm{Fe}$ & 57.1 & 464.2 & 1691.1 & 18.2 & 540.6 & 2174.3 & ND & 66.3 & 473.2 & ND & 17.9 & 140.9 & 163.1 & 661.2 & 1536.1 \\
\hline Sr & 0.0 & 1.2 & 7.5 & ND & 4.4 & 37.2 & 0.1 & 1.5 & 23.4 & 0.2 & 0.8 & 14.6 & 1.0 & 23.5 & 78.5 \\
\hline $\mathrm{Y}$ & 574.6 & 2379.0 & 3994.1 & 314.5 & 720.7 & 2964.0 & 234.6 & 622.5 & 1936.7 & 441.3 & 772.3 & 1910.1 & 534.5 & 869.3 & 1422.1 \\
\hline $\mathrm{Nb}$ & 1.5 & 5.9 & 12.8 & 0.6 & 3.7 & 21.7 & 1.2 & 1.7 & 2.8 & 1.9 & 2.7 & 5.0 & 1.0 & 3.3 & 7.9 \\
\hline $\mathrm{Hf}$ & 6554.2 & 8939.7 & $11,773.4$ & 6650.0 & 8938.0 & $11,683.0$ & 6145.0 & 8442.4 & $10,388.0$ & 7282.4 & 8442.1 & $10,974.9$ & 5964.2 & 8091.6 & $10,938.2$ \\
\hline $\mathrm{Ta}$ & 0.1 & 2.3 & 5.6 & 0.0 & 0.3 & 1.8 & 0.0 & 0.3 & 2.7 & 0.2 & 0.4 & 1.6 & ND & 0.4 & 1.5 \\
\hline Th & 140.7 & 221.1 & 315.4 & 50.6 & 204.4 & 540.5 & 34.2 & 154.0 & 641.5 & 31.3 & 69.6 & 185.1 & 237.2 & 498.5 & 960.0 \\
\hline $\mathrm{U}$ & 269.4 & 413.8 & 524.0 & 111.7 & 244.8 & 543.7 & 43.9 & 146.8 & 481.3 & 44.5 & 80.9 & 256.8 & 292.8 & 522.8 & 785.0 \\
\hline $\mathrm{La}$ & ND & 2.8 & 27.7 & 0.0 & 8.6 & 143.8 & 0.0 & 0.1 & 0.6 & 0.0 & 0.1 & 1.3 & 0.0 & 16.0 & 87.2 \\
\hline $\mathrm{Ce}$ & 4.3 & 17.2 & 61.4 & 2.4 & 77.6 & 796.7 & 16.7 & 35.4 & 99.6 & 15.9 & 28.9 & 49.6 & 54.9 & 158.5 & 463.7 \\
\hline $\mathrm{Pr}$ & ND & 1.1 & 7.9 & 0.0 & 7.8 & 127.3 & 0.0 & 0.4 & 1.1 & 0.0 & 0.2 & 0.9 & 0.0 & 9.8 & 52.0 \\
\hline $\mathrm{Nd}$ & 0.6 & 7.7 & 44.4 & 0.7 & 54.2 & 709.8 & 0.9 & 6.0 & 14.7 & 0.6 & 2.5 & 7.4 & 0.8 & 66.5 & 335.5 \\
\hline $\mathrm{Sm}$ & 1.8 & 8.2 & 25.6 & 0.0 & 27.2 & 209.5 & 1.6 & 7.0 & 17.8 & 1.5 & 4.2 & 7.0 & 3.4 & 20.9 & 86.8 \\
\hline $\mathrm{Eu}$ & 0.4 & 1.3 & 5.0 & 0.6 & 11.0 & 72.8 & 0.3 & 2.1 & 12.3 & 0.5 & 1.3 & 2.1 & 0.4 & 6.7 & 25.9 \\
\hline $\mathrm{Gd}$ & 9.0 & 45.0 & 78.3 & 6.9 & 48.2 & 332.0 & 6.0 & 22.0 & 74.6 & 9.4 & 19.0 & 43.9 & 12.6 & 31.1 & 80.8 \\
\hline $\mathrm{Tb}$ & 3.7 & 16.4 & 28.4 & 1.6 & 9.0 & 58.0 & 1.8 & 5.3 & 17.6 & 2.7 & 5.5 & 14.9 & 2.3 & 6.4 & 14.8 \\
\hline Dy & 35.0 & 196.9 & 327.4 & 22.0 & 77.4 & 453.9 & 17.8 & 55.1 & 183.8 & 35.2 & 64.8 & 183.1 & 34.3 & 61.9 & 106.0 \\
\hline Ho & 14.9 & 80.4 & 132.7 & 8.5 & 22.5 & 108.8 & 7.3 & 19.0 & 63.7 & 12.1 & 24.0 & 66.3 & 11.4 & 22.5 & 41.2 \\
\hline Er & 69.1 & 370.4 & 613.4 & 35.6 & 91.9 & 366.8 & 36.2 & 89.1 & 279.6 & 73.0 & 122.4 & 313.9 & 69.7 & 110.2 & 181.3 \\
\hline $\mathrm{Tm}$ & 14.4 & 76.0 & 121.7 & 5.6 & 17.8 & 61.5 & 7.9 & 18.7 & 49.7 & 16.0 & 25.8 & 58.0 & 16.4 & 23.9 & 40.6 \\
\hline $\mathrm{Yb}$ & 150.6 & 677.9 & 1076.7 & 45.9 & 163.9 & 441.1 & 79.4 & 185.2 & 461.5 & 169.0 & 256.2 & 528.7 & 158.9 & 247.1 & 386.8 \\
\hline $\mathrm{Lu}$ & 32.1 & 137.0 & 213.1 & 8.4 & 35.3 & 68.8 & 17.2 & 41.7 & 104.5 & 36.3 & 54.5 & 103.8 & 35.7 & 51.0 & 71.6 \\
\hline $\mathrm{La} / \mathrm{Yb}_{\mathrm{N}}$ & $4 \mathrm{E}-06$ & $6 \mathrm{E}-03$ & $6 \mathrm{E}-02$ & $5 \mathrm{E}-05$ & $4 \mathrm{E}-02$ & $6 \mathrm{E}-01$ & $5 E-05$ & $4 \mathrm{E}-04$ & $1 \mathrm{E}-03$ & $6 \mathrm{E}-06$ & $3 \mathrm{E}-04$ & $4 \mathrm{E}-03$ & $4 \mathrm{E}-03$ & $5 \mathrm{E}-02$ & $2 \mathrm{E}-01$ \\
\hline $\mathrm{Eu} / \mathrm{Eu}^{*}$ & 0.1 & 0.3 & 0.8 & 0.5 & 1.0 & 3.2 & 0.3 & 0.6 & 4.6 & 0.3 & 0.4 & 0.6 & 0.4 & 0.9 & 1.4 \\
\hline $\mathrm{Ce} / \mathrm{Ce}^{*}$ & 0.9 & 29.8 & 195.8 & 0.7 & 17.6 & 145.1 & 5.9 & 22.1 & 76.6 & 7.5 & 63.6 & 241.9 & 0.8 & 4.7 & 29.8 \\
\hline $\mathrm{T}\left({ }^{\circ} \mathrm{C}\right)$ & 571.2 & 679.9 & 826.3 & 538.1 & 845.0 & 1990.4 & 565.2 & 719.8 & 860.0 & 641.6 & 718.1 & 980.0 & 583.8 & 888.3 & 1147.2 \\
\hline
\end{tabular}




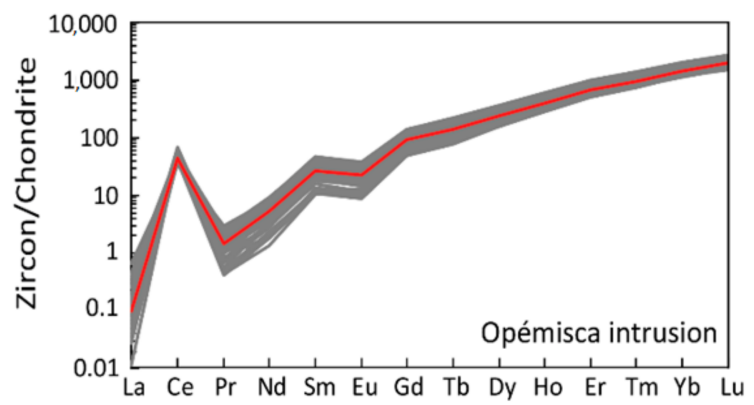

(a)

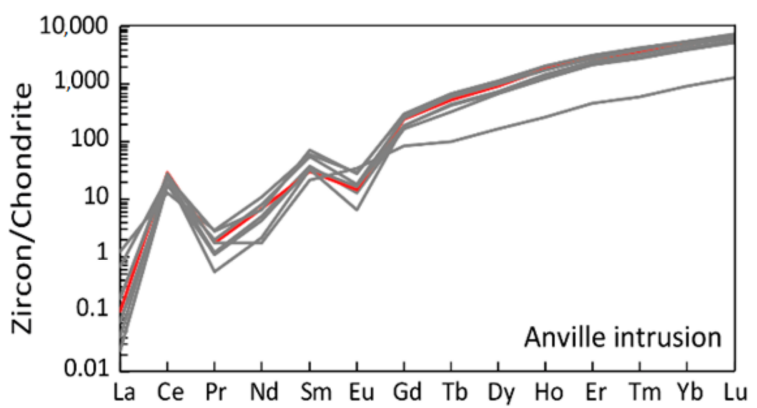

(c)

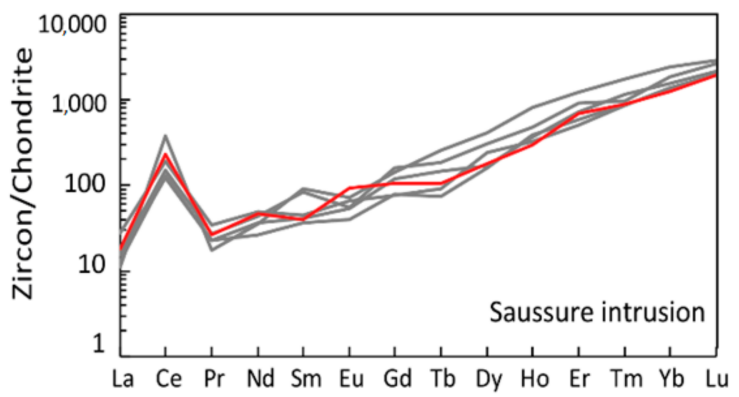

(b)

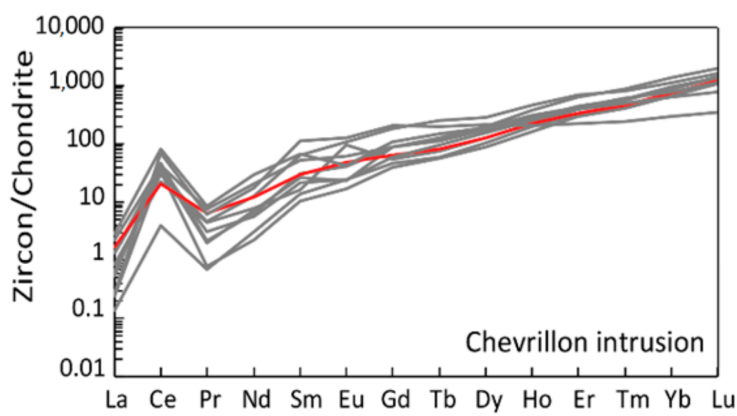

(d)

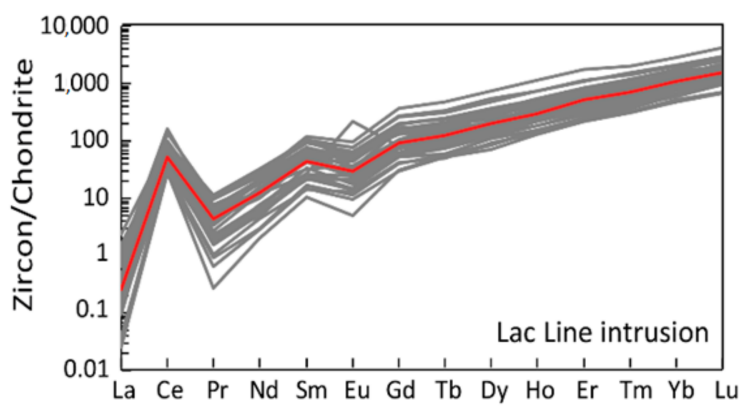

(e)

Figure 7. Chondrite- normalized REE pattern for the zircons of the (a) Opémisca, (b) Saussure, (c) Anville, (d) Chevrillon, and (e) Lac Line intrusions. Red lines correspond to mean values. Data are normalized to the chondrite [60].

\subsection{Volatile Content of the Melt}

The volatile content (mainly $\mathrm{Cl}, \mathrm{S}$, and $\mathrm{H}_{2} \mathrm{O}$ ) of a magma is an essential factor for the formation of IRGS, as it permits the formation of $\mathrm{Cl}$ - and S-complexes that transport metals, such as $\mathrm{Au}$ and $\mathrm{Cu}$, through the crust [9]. In this section, apatite and amphibole chemistry is used to estimate the volatile content $\left(\mathrm{H}_{2} \mathrm{O}, \mathrm{S}\right.$, and $\left.\mathrm{Cl}\right)$ of the studied magmas.

As the Anville and Lac Line intrusions lack amphiboles, only the $\mathrm{H}_{2} \mathrm{O}$ concentration of the Saussure, Chevrillon, and Opémisca intrusions is estimated using an empirical amphibole formulation $[74,75]$. The melt in equilibrium with the Saussure, Chevrillon, and Opémisca amphiboles yield $\mathrm{H}_{2} \mathrm{O}$ concentrations of 3.7 to $4.5 \mathrm{wt} . \%$, 5.4 to $5.5 \mathrm{wt} . \%$, and 3.7 to $4.1 \mathrm{wt} . \%$, respectively.

Apatite from the Chevrillon, Opémisca, and Anville intrusions display low sulfur content $\left(<0.1 \mathrm{wt} . \% \mathrm{SO}_{3}\right)$. These low values may reflect low $\mathrm{S}$ concentration in the melt. In a reduced magmatic environment (Anville intrusion), $\mathrm{S}$ is mostly dissolved in the magma as sulfur $\left(\mathrm{S}^{2-}\right)$, which is more incompatible than sulfate $\left(\mathrm{S}^{6+}\right)$ in apatite [66]. On the other hand, the moderate to elevated $S$ content ( 0.2 to $0.5 \mathrm{wt} . \% \mathrm{SO}_{3}$ ) observed in the apatite from the Saussure and Lac Line intrusions may indicate that $\mathrm{S}$ was introduced in the structure of apatite by secondary processes. To comment on the S-content 
of the melt, the empirical partitioning relationship of $S$ between apatite and rhyolitic/andesitic melt is applied Equation (7) [84].

$$
S_{\text {apatite }}=0.0629 \times \ln S_{\text {melt }}+0.4513
$$

with $S_{\text {apatite }}$ and $S_{\text {melt }}$ the $S$ content in ppm in apatite and melt, respectively.

For the Chevrillon, Opémisca, and Anville intrusions, this method points to magmas with low S-contents of about 10 to $30 \mathrm{ppm} \mathrm{S.} \mathrm{On} \mathrm{the} \mathrm{other} \mathrm{hand,} \mathrm{the} \mathrm{Saussure} \mathrm{and} \mathrm{Lac} \mathrm{Line} \mathrm{intrusions} \mathrm{return}$

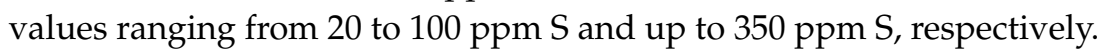

The studied apatites are also $\mathrm{Cl}$-poor $(<0.1 \mathrm{wt} . \% \mathrm{Cl})$ and there are no significant differences between altered and unaltered apatite, which mean that it could be a pristine value. To estimate the $\mathrm{Cl}$ concentration of the melt, we used a thermodynamic apatite/melt chlorine partitioning model (Equations (8) and (9)) [85]:

$$
C l_{\text {melt }}=\frac{X_{C l}^{a p}}{X_{O H}^{a p}} \frac{1}{K d_{C l-O H}^{a p-m e l t}} \times 10.79
$$

where $X_{\mathrm{Cl}}^{a p}$ and $\mathrm{X}_{\mathrm{OH}}^{a p}$ are the mole fractions of chlorapatite and hydroxylapatite estimated by calculating the structural formula of apatite [85]

$$
K d_{C l-O H}^{a p-m e l t}=e^{\left(25.81+\left(X_{C l}^{a p}-X_{O H}^{a p}\right) \times 17.33\right) \times \frac{10^{3}}{8.314 \times T}}
$$

with $\mathrm{T}$ the temperature in $\mathrm{K}[86]$.

Using this method, we obtain $\mathrm{Cl}$ melt concentrations that range from less than 0.01 to $0.1 \mathrm{wt} . \%$ $\mathrm{Cl}$. Only three apatite grains from the Lac Line and Saussure intrusions return values of $0.1 \mathrm{wt} . \% \mathrm{Cl}$ in the melt. The studied magmas present $\mathrm{H}_{2} \mathrm{O}, \mathrm{S}$ and $\mathrm{Cl}$ values within the range expected for felsic magmas $[75,86]$. Only the Saussure and Lac Line intrusions show S-content anomalously elevated, but these values need further validation.

\subsection{Oxidation State}

Redox conditions at the time of crystallization were estimated using the trace element chemistry of apatite and zircon (Supplementary Material Table S2). Three types of apatite are distinguished on the basis of their respective Eu anomalies (Figure 8), which is a proxy for the $f \mathrm{O}_{2}$ parameter [51]. According to apatite chemistry, the Anville intrusion crystallized under the lowest $f \mathrm{O}_{2}$ conditions (type 1 apatite; Figure 8). The Lac Line apatites point to slightly higher $f \mathrm{O}_{2}$ conditions (type 2 apatite). The Saussure and Chevrillon intrusions crystallized under the highest $f \mathrm{O}_{2}$ conditions (type 3 apatite). Variation of $f \mathrm{O}_{2}$ values is limited in individual intrusions, except for the Opémisca Pluton that displays a range of Eu anomalies values (types 2 and 3 apatites observed; Figure 8).

$\mathrm{The} \mathrm{Eu} / \mathrm{Eu}^{*}$ vs. $\mathrm{Ce} / \mathrm{Ce}^{*}$ in zircon oxy-barometer [51] has been used on pristine zircon to further evaluate the $f \mathrm{O}_{2}$ parameter. Two zircon populations are observed on the basis of their Eu anomalies (Figure 9). Both populations display a wide range of Ce anomalies ( 0.9 to 100). Population 1 zircon is composed of zircon from the Anville intrusion and displays a generally lower Eu anomaly (up to 0.1), except for two grains that display high Eu anomaly. Population 2 is composed of zircons from the Lac Line, Saussure, Chevrillon, and Opémisca intrusions and displays a moderate Eu anomaly (0.1 to 0.3) except for few grains from the Anville, Chevrillon, and Saussure intrusions with Eu anomalies up to 1. Results of zircon from the Saussure, Chevrillon, Lac Line, and Opémisca intrusions suggest that they crystallized under more elevated $f \mathrm{O}_{2}$ conditions than zircons from the Anville intrusion, which crystallized under the lowest $f \mathrm{O}_{2}$ conditions. 


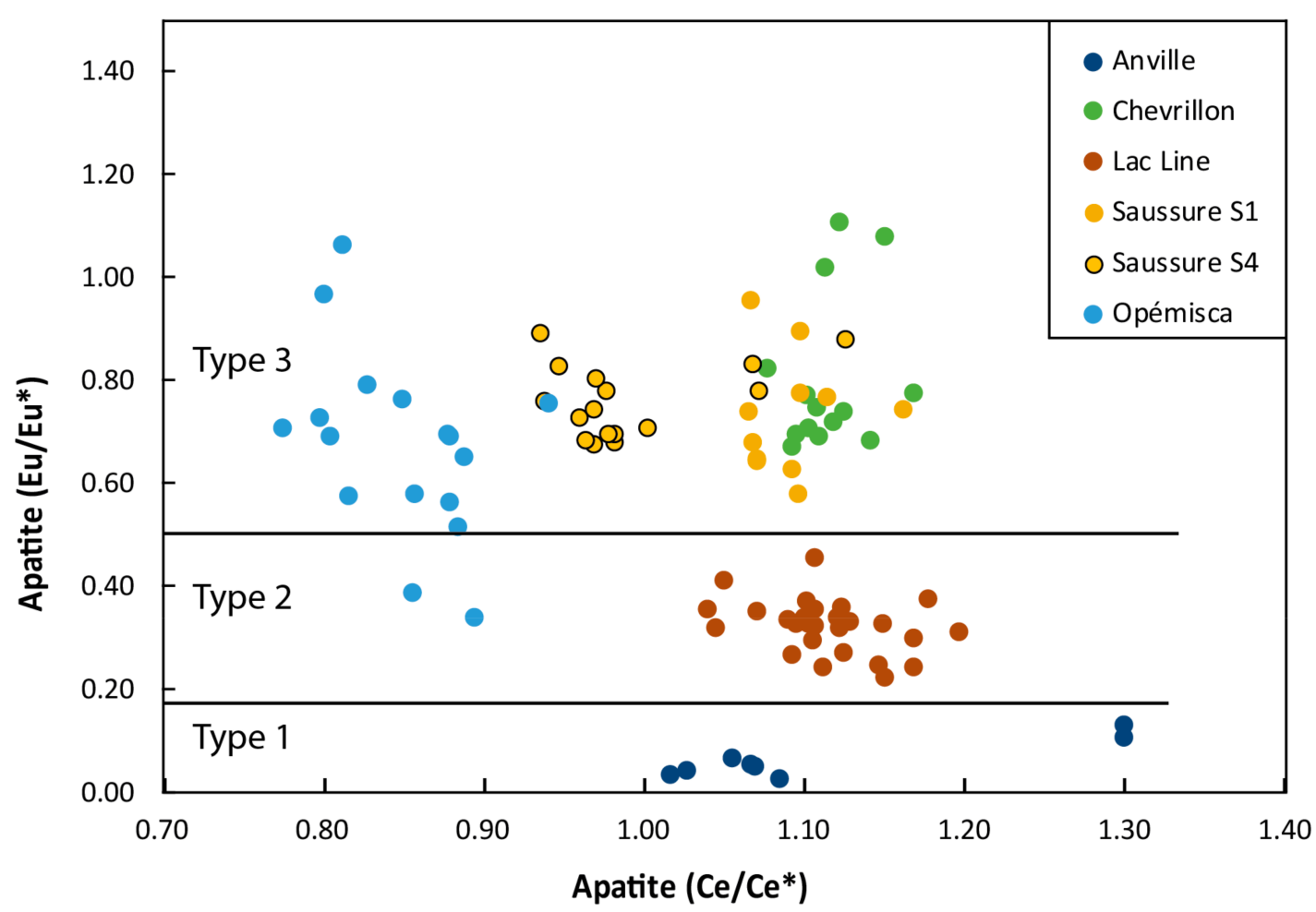

Figure 8. Diagram displaying the Eu anomalies $\left(\mathrm{Eu} / \mathrm{Eu}^{*}\right)$ vs. Ce anomalies $\left(\mathrm{Ce} / \mathrm{Ce}^{*}\right)$ of apatite; with $\mathrm{Eu}^{*}=0.5^{*}\left(\mathrm{Sm}_{\mathrm{N}}+\mathrm{Gd}_{\mathrm{N}}\right), \mathrm{Ce}^{*}=0.5^{*}\left(\mathrm{La}_{\mathrm{N}}+\mathrm{Pr}_{\mathrm{N}}\right)$. Limits between these three types are defined according to previous studies $[64,67]$. The S1 and S4 samples from the Saussure intrusion are from granite and syenite phases, respectively. Data are normalized to chondrite [60].

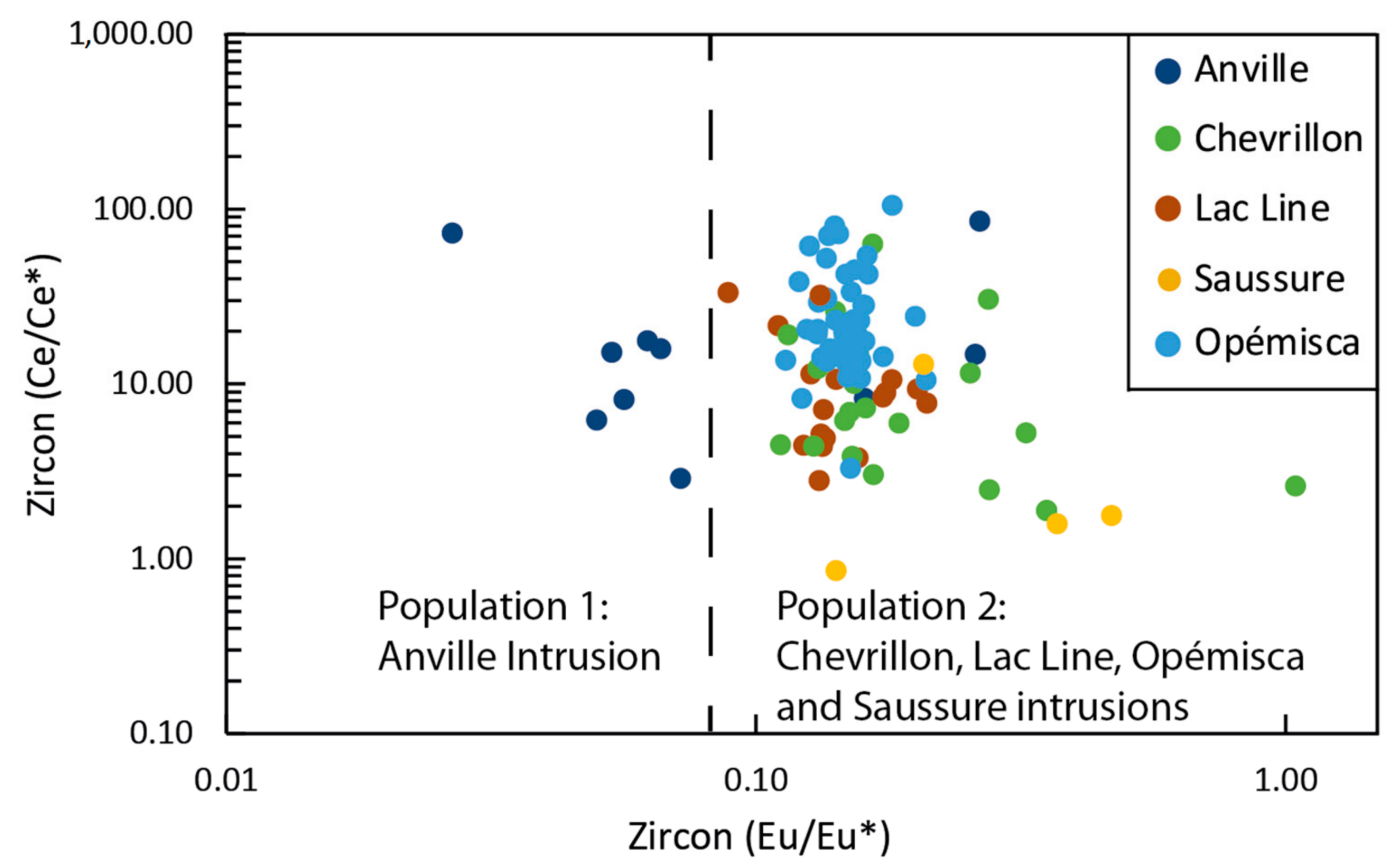

Figure 9. Diagram displaying the $\left(\mathrm{Ce} / \mathrm{Ce} e^{*}\right)$ vs. $\left(\mathrm{Eu} / \mathrm{Eu}^{*}\right)$ in pristine zircon; with $\mathrm{Ce}^{*}=(\mathrm{Nd})^{2}{ }_{\mathrm{N}} /(\mathrm{Sm})_{\mathrm{N}}$; $\mathrm{Eu}^{*}=0.5^{*}\left(\mathrm{Sm}_{\mathrm{N}}+\mathrm{Gd}_{\mathrm{N}}\right)$. Data are normalized to chondrite [60]. 
The $\left(\frac{C e}{C e^{*}}\right)_{C H U R}$ oxybarometer $[68,69]$ and the REE-independent $\left[\begin{array}{l}X_{C^{4+}}^{\text {melt }} \\ X_{C c^{3+}}^{\text {melt }}\end{array}\right]$ oxybarometer $[70]$ have been applied to the studied zircons to calculate the $f \mathrm{O}_{2}$ parameter (Figure 10a). These methods provide distinct results. The $\left(\frac{C e}{C e^{*}}\right)_{C H U R}$ oxybarometer returns, at similar temperatures, a wide range of $f \mathrm{O}_{2}$ values for individual intrusions, e.g., $\triangle \mathrm{FMQ}$ from -0.2 to +9.3 for the Opémisca intrusions at $750{ }^{\circ} \mathrm{C}$ (Figure 10b). There is a discrepancy between these results and the results obtained with the other methods applied to the studied samples, which returned a narrow range of $f \mathrm{O}_{2}$ values for individual intrusions.

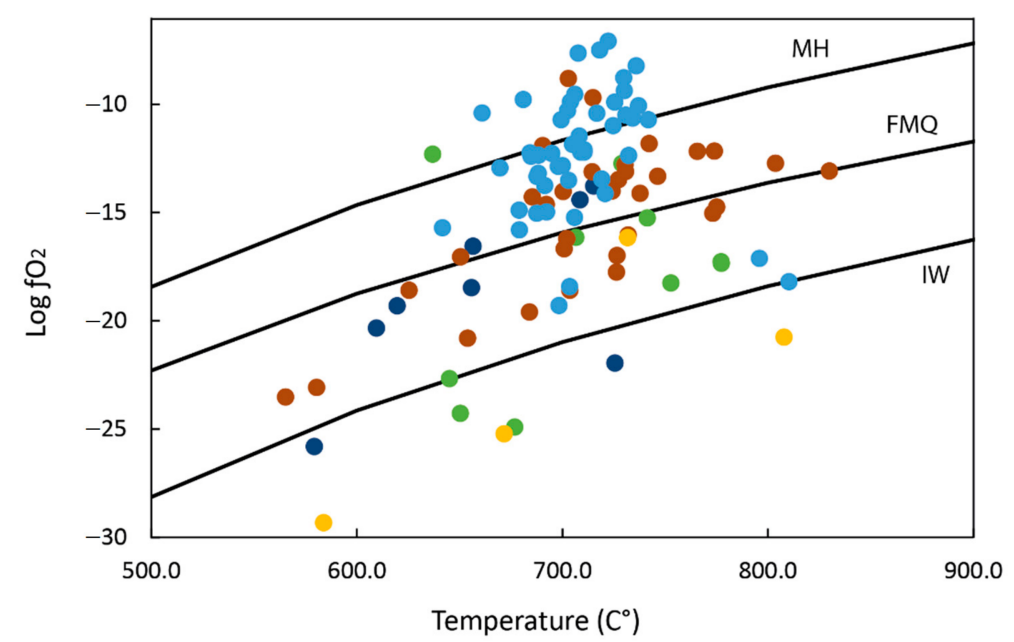

(a)

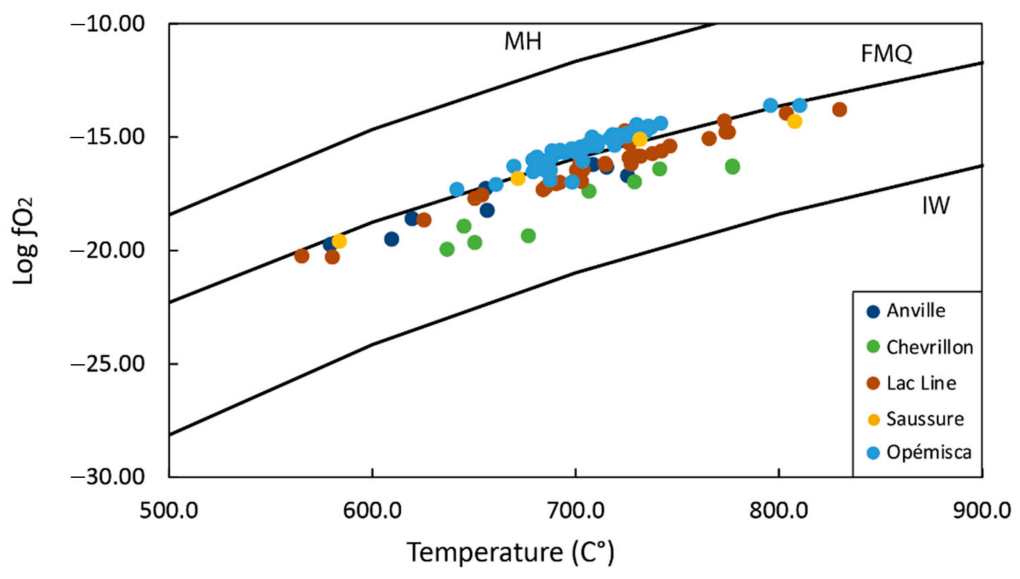

(b)

Figure 10. Diagram displaying the results of the (a) $\left(\frac{C e}{C e *}\right)_{C H U R}$ oxybarometer [68,69] and

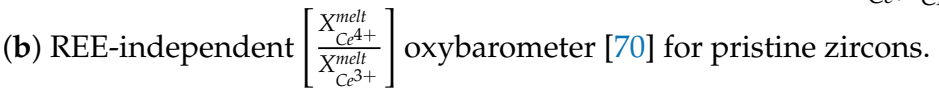

The REE-independent $\left[\frac{X_{C 4^{4+}}^{\text {melt }}}{X_{C^{3+}}^{m e l t}}\right]$ oxybarometer (Figure 10b) returns a narrow range of $f \mathrm{O}_{2}$ values for individual intrusions. According to this method, the synvolcanic Anville intrusion crystallized under the lowest and highest $f \mathrm{O}_{2}$ conditions with mean $\triangle \mathrm{FMQ}$ of -1.4 . The Lac Line, Chevrillon zircons point to intermediate $f \mathrm{O}_{2}$ values with mean $\triangle \mathrm{FMQ}$ values of -0.3 and -0.7 , respectively. The Saussure and Opémisca Intrusions show higher $f \mathrm{O}_{2}$ values with mean $\triangle \mathrm{FMQ}$ values of 0.7 . 


\subsection{Geochronology Results}

The U-Pb ratios and trace element composition were measured on zircon from the Anville, Saussure, and Chevrillon intrusions (Supplementary Material Table S3). Overall, the zircons from each sample display characteristics of moderate to severe alteration-related Pb-loss, a feature common to Archean zircons that have experienced significant radiation damage accumulation. Additionally, there is a slight overdispersion in the ${ }^{238} \mathrm{U} /{ }^{206} \mathrm{~Pb}$ due to variable ablation rates relative to the OGC primary reference material (also a byproduct of variable damage).

Analyses within the filter criteria yielded intercept ages of $2697 \pm 11 \mathrm{Ma}$ for the Chevrillon (Mean Squared Weighted Deviation $(\mathrm{MSWD})=1.9 ; \mathrm{Sr}<8 \mathrm{ppm}$ ) and $2688 \pm 8 \mathrm{Ma}$ for the Saussure (MSWD $=0.2 ; \mathrm{Sr}<12 \mathrm{ppm}$ ) intrusions, respectively (Figure 11). Zircons from the Anville intrusion have mostly concordant ages with an intercept age of $2796.5 \pm 3.8 \mathrm{Ma}$ (MSWD $=0.53$; $\mathrm{Sr}<2 \mathrm{ppm}$; Figure 11), which we interpret as recording the timing of primary crystallization [48].
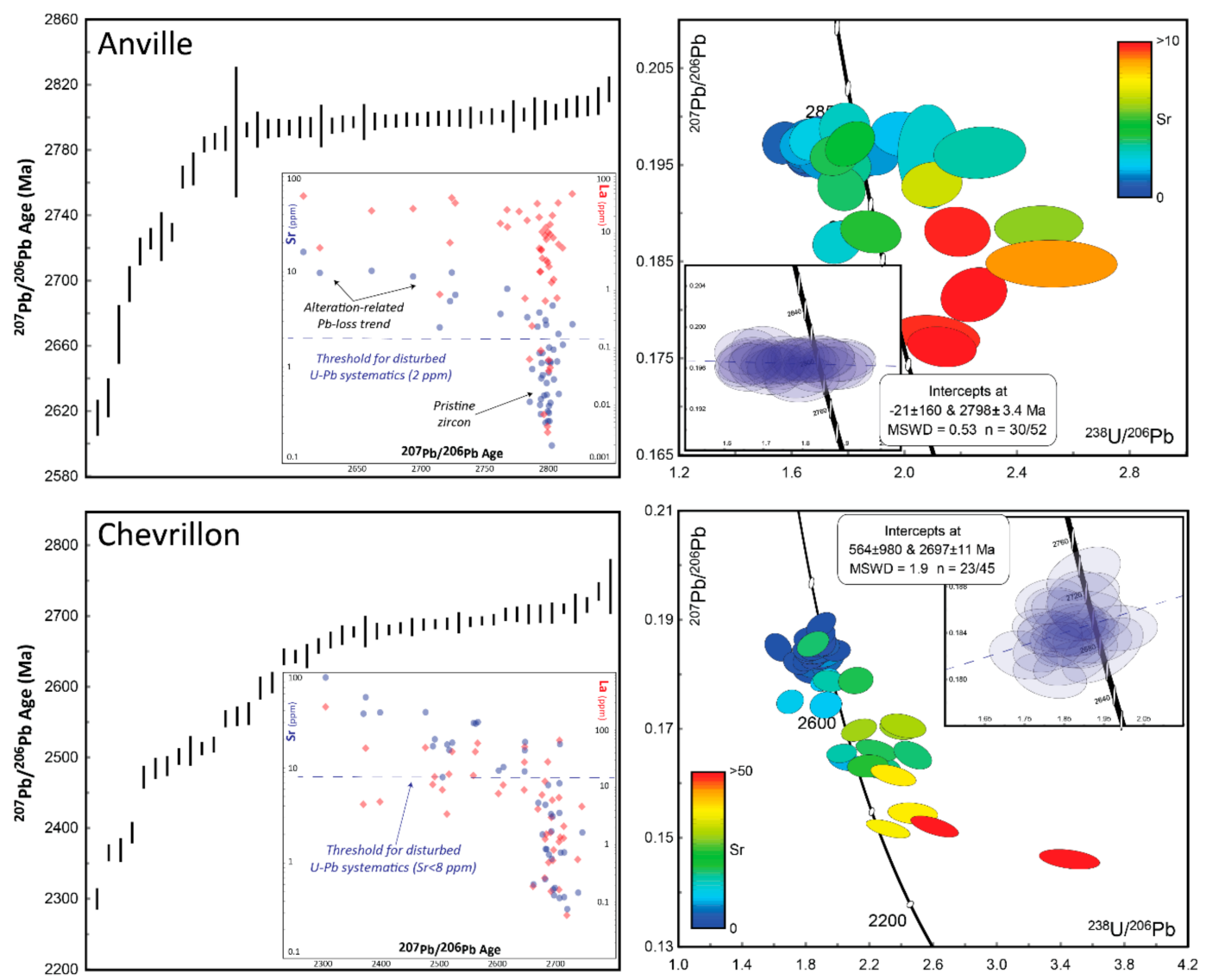

Figure 11. Cont. 

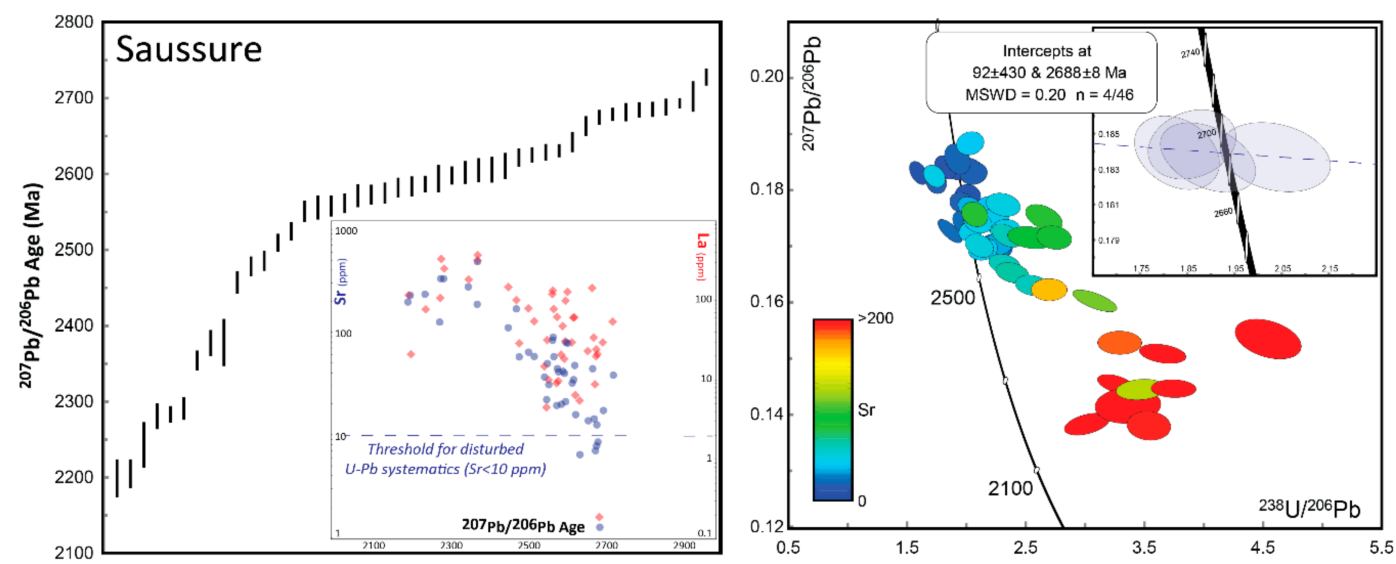

Figure 11. Zircon U-Pb age spectra (left) and Concordia diagrams (right) for the Anville, Chevrillon, and Saussure intrusions. Age spectra inset shows relationship between individual ${ }^{207} \mathrm{~Pb} /{ }^{206} \mathrm{~Pb}$ dates and $\mathrm{Sr}$ and La concentrations. The threshold value for data filtering is defined by departure from vertical array. Ellipses in Concordia diagrams are colored for Sr concentration (ppm). Inset shows data conforming to filter criteria for each sample, from which sample crystallization ages are calculated.

\section{Discussion}

\subsection{Magma Type}

The studied intrusions are alkaline to subalkaline and correspond to differentiated magmas according to their alkali and silica contents (Table 3). In this section, magmas types are characterized using a recent classification of plutonic rocks [19].

The Anville and Lac Line intrusions have the chemical composition of TTG suites, as defined by Moyen [19]. The Lac Line intrusion has the characteristics of a high pressure (HP) TTG suite, with $\mathrm{K}_{2} \mathrm{O} / \mathrm{Na}_{2} \mathrm{O}<0.2 \mathrm{wt}$.\%, high $\mathrm{Na}_{2} \mathrm{O}$ content, lack of $\mathrm{K}$-feldspar (Figure $4 \mathrm{~b}$, Table 2 ) and a strong fractionation of the LREE over the HREE (Figure 4c). However, the $\mathrm{Fe}, \mathrm{Mg}$, and $\mathrm{Al}$ contents (for $70 \mathrm{wt.} \% \mathrm{SiO}_{2}$ ) of the Lac Line intrusion are higher than these of HP TTG suites (Table 3). Classification of the Lac Line intrusion remains uncertain, as extensive hydrothermal alteration likely modified its major element chemistry. The Anville intrusion resembles a K-rich TTG as it displays chemical characteristics of TTG suites, as well as these of ordinary biotite granite, such as relatively elevated $\mathrm{K}$ content $\left(\mathrm{K}_{2} \mathrm{O} / \mathrm{Na}_{2} \mathrm{O}=0.56\right)$ and elevated high field strength elements (HFSE) content (e.g., $35 \mathrm{ppm} \mathrm{Y,}$ Figure 4).

The Opémisca intrusion has a spotted macroscopic aspect that is common in sanukitoid intrusions [19,46]. This intrusion is also Na-K-rich $\left(4.80 \mathrm{wt} . \% \mathrm{Na}_{2} \mathrm{O}\right.$ and $\left.3.16 \mathrm{wt} . \% \mathrm{~K}_{2} \mathrm{O}\right)$ with a $\mathrm{K}_{2} \mathrm{O} / \mathrm{Na}_{2} \mathrm{O}$ ratio of 0.66 and has elevated $\mathrm{Sr}(1165 \mathrm{ppm})$ and $\mathrm{La}(30 \mathrm{ppm})$ contents (Table 3). The Opémisca intrusion, thus, has the whole-rock composition of a sanukitoid intrusion $[19,87,88]$ to the exception that it is slightly peraluminous (aluminum saturation index (ASI) $=1.0-1.1$ ) while sanukitoids tend to be metaluminous (ASI < 1, Figure 4) [19]. This Al-enrichment and Ca-depletion may be the results of alteration that induced the saussuritization observed in calcic plagioclase. This alteration could be due to sub-solidus reactions between intrusive rocks and tardi-magmatic fluids.

The Chevrillon intrusion is a high-K calc-alkaline (HKCA) granitoid intrusion [41] with large phenocrysts of K-feldspar (Figure 2e) and elevated $\mathrm{K}_{2} \mathrm{O}\left(3.1 \mathrm{wt} . \% \mathrm{~K}_{2} \mathrm{O}\right.$ ) and $\mathrm{Sr}$ contents (1200 to $1400 \mathrm{ppm})$. The intrusion also has sanukitoid chemical characteristics, with a $\mathrm{K}_{2} \mathrm{O} / \mathrm{Na}_{2} \mathrm{O}$ ratio of 0.6 and high contents of LREE (200-ppm sum LREE). Moreover, the HKCA group has been defined recently [19] and its chemical definition likely requires refinement. This intrusion is also slightly peraluminous (ASI $=1.0-1.1$ ), but that may be a consequence of secondary processes.

The Saussure intrusion is a typical quartz-bearing alkali syenite. This intrusion has elevated alkali $\left(\mathrm{Na}_{2} \mathrm{O}+\mathrm{K}_{2} \mathrm{O}-\mathrm{CaO}=9\right.$ wt.\%) and incompatible elements contents (up to $200 \mathrm{ppm} \mathrm{Rb}$, up 
to $1300 \mathrm{ppm}$ Sr, $550 \mathrm{ppm}$ ¿REE, Table 3), which is typical of alkaline magmatism of any geological period [19].

\subsection{Zircon $U-P b$ Geochronology}

The results reported here indicate that the age $(2796.5 \pm 3.8 \mathrm{Ma})$ reported for the Anville intrusion (Figure 11) is similar to that of the Chrissie and Des Vents formations, which formed in the early stage of the synvolcanic period. This age is also much older than the previous synvolcanic age (2714.8 $\pm 0.6 \mathrm{Ma})$ reported for the Anville intrusion [48]. The Anville intrusion is likely an assemblage of synvolcanic and syntectonic intrusions emplaced in a restricted area throughout the evolution of the Chibougamau area. The syntectonic component was likely emplaced in the highly deformed southern part of the pluton that remains undated [35]. This intrusion is covered by quaternary material and the paucity of exposed outcrops prevents detailed investigation of crosscutting relationships.

For the Saussure and Chevrillon intrusions, the larger proportion of zircon that have undergone alteration and $\mathrm{Pb}$-loss has resulted in slightly higher age uncertainty. The Chevrillon intrusion crystallization age of $2697 \pm 11 \mathrm{Ma}$ (Figure 11) is in good agreement with recent yet unpublished TIMS age for the intrusion of $2693.1 \pm 1.7 \mathrm{Ma}$ [41]. This and the intrusion's crosscutting relationships with the Chebistuan Formation confirm that the intrusion is syntectonic (Figure 1). Moreover, the Saussure intrusion has likely an age of crystallization of $2688 \pm 8 \mathrm{Ma}$ (Figure 11), which is in good agreement with stratigraphic relationships. Indeed, the Saussure intrusion emplaced in the Daubrée Formation (Figure 1), which formed during the syntectonic period.

In summary, the studied intrusions formed within about 10 Ma during the syntectonic period. Only the sample from the Anville intrusion is older and may be representative of synvolcanic magmatism.

\subsection{Impact of Alteration on Mineral Chemistry and $\mathrm{fO}_{2}$ Estimates}

One of the main objectives of this study is to determine how the $f \mathrm{O}_{2}$ parameter of Archean magmas can be evaluated using rocks that have generally been hydrothermally altered within magmatic-hydrothermal mineralizing systems. Apatite and zircon from the studied intrusions are more or less altered, as indicated by textural changes and heterogeneous chemistry (as discussed below).

Apatite from the Lac Line and Opémisca intrusions is strongly altered according to textural observations, i.e., porous texture, abundance of cracks, lack of oscillatory zoning and resorption texture. This alteration is accompanied by variation of the $\mathrm{Na}, \mathrm{Si}, \mathrm{Fe}, \mathrm{K}, \mathrm{Al}$, and $\mathrm{S}$ content of apatite and by REE remobilization that is likely a consequence of hydrothermal alteration $[67,89,90]$ and/or of the co-crystallization of accessory minerals, such as monazite and feldspar [91,92].

As shown by the CL and BSE images (Figure 5) as well as the Sr- and LREE-contents (Figure 3), most zircon from the Chevrillon and Saussure intrusions, and some zircon from the Anville intrusion are strongly altered. Alteration is manifested by corroded rims, porous textures, lack of oscillatory zoning, porosity of the core, as well as concentric and non-concentric cracks. Preserved oscillatory zoning (Figure 5) and resorption in other grains, point to complex crystallization history. Altered zircons may be enriched in trace (e.g., $\mathrm{Ca}, \mathrm{P}, \mathrm{Al}, \mathrm{Fe}, \mathrm{Sr}$, and $\mathrm{Ti}$ ) elements compared to unaltered zircons $[57,58,93]$. Gain of trace elements may also be due to coupled substitution of non-formula elements $[94,95]$ and to inclusions of feldspar, quartz or apatite [96-98]. Local decrease of the $\mathrm{Zr}, \mathrm{Pb}$, $\mathrm{Hf}$, and Si content may also be due to intense metamictization [95].

Modification of apatite and zircon chemistry also impacts the results of Ti-in-zircon thermometry and $f \mathrm{O}_{2}$ estimations. In felsic and intermediate intrusions, the Ti-content of zircon is generally less than $20 \mathrm{ppm}$, which corresponds to average crystallization temperatures of $653 \pm 124{ }^{\circ} \mathrm{C}$ and $758 \pm 98{ }^{\circ} \mathrm{C}$, respectively [99]. Alteration $[95,97]$ or the entrapment of co-precipitated phases $[57,58]$ may explain $\mathrm{Ti}$ enrichment (up to $150 \mathrm{ppm} \mathrm{Ti),} \mathrm{which} \mathrm{lead} \mathrm{to} \mathrm{unreliable} \mathrm{temperature} \mathrm{estimates} \mathrm{[100].}$

The $f \mathrm{O}_{2}$ values obtained from REE dependent method [51,67,69] provide significantly different results when applied to pristine and non-pristine apatite and zircon grains, as was also noted for the 
Muscocho Pluton [101]. For example, the apatites from the Opémisca intrusion provide a wide range of $\log \left(f \mathrm{O}_{2}\right)$ estimates from $-17.2{ }^{\circ} \mathrm{C}$ to -18.3 at $700{ }^{\circ} \mathrm{C}$. The lowest $f \mathrm{O}_{2}$ values are likely due to LREE-rich inclusions. Apatites from the Lac Line intrusion are strongly and evenly altered, which induced REE depletion and lead to underestimation of the $f \mathrm{O}_{2}$ parameter.

\subsection{Oxidation State and Magma Temperature}

As discussed in the previous section, most apatites from the Lac Line and Opémisca intrusions and most zircons from the Saussure and Chevrillon intrusions are non-pristine. For this reason, the $f \mathrm{O}_{2}$ parameter may be best estimated by comparing results obtained from two minerals, i.e., apatite and zircon. In this section, non-pristine grains are no longer considered, and results obtained from pristine apatite and zircon are compared.

Zircon crystallization temperature estimated using the Ti-in-zircon method [61] returned median temperatures of crystallization of $650{ }^{\circ} \mathrm{C}$ to $720^{\circ} \mathrm{C}$ for the pristine zircon (Figure 10). These are reasonable temperatures for the last stage of magma crystallization [102,103]. Note that the alkaline intrusion (Saussure) contained only four least-altered zircons and temperature estimates are the least reliable for this intrusion.

The chondrite normalized (CHUR) oxybarometer [69] uses the La content of zircon and seems to be the least reliable method, as results cross many buffers, and are uncorrelated with results obtained using other methods. The CHUR-method is strongly dependent on the quality of the La measurement and to La-increase induced by alteration and La-rich inclusions [56-58], as is observed in the studied zircons. This method is likely unreliable in hydrothermally altered contexts.

While the $\mathrm{Eu} / \mathrm{Eu}^{*}$ vs. $\mathrm{Ce} / \mathrm{Ce} \mathrm{e}^{*}$ ratio method provides an estimation of the $\mathrm{fO}_{2}$ parameter, results are comparable with the other methods. This method may be reliable, and its results will be compared to results obtained from the other zircon oxybarometer. Elevated oxygen fugacity corresponds to low values of the $\mathrm{Eu}^{2+} / \mathrm{Eu}^{3+}$ ratio in magma, leading to a low Eu negative anomaly in apatite and zircon. $\mathrm{The} \mathrm{Eu} / \mathrm{Eu}^{*}$ vs. $\mathrm{Ce} / \mathrm{Ce}^{*}$ ratio points to oxidizing to moderately oxidizing conditions for most intrusions, except for the synvolcanic Anville intrusion that records reduced conditions.

According to the $\left[\frac{X_{\mathrm{Ce}^{4+}}^{\text {melt }}}{X_{\mathrm{C}^{3+}}^{m e l t}}\right]$ oxybarometer [70], zircon containing $<0.1 \mathrm{ppm}$ La crystallized in reduced conditions $(\triangle \mathrm{FMQ}$ of -1.4$)$ for the Anville intrusion and moderately reduced conditions $(\triangle \mathrm{FMQ}$ of -0.3 to -0.7$)$ for the Lac Line and Chevrillon intrusions. Zircons from the Opémisca and Saussure intrusions return even more elevated values ( $\triangle \mathrm{FMQ}$ of 0.7 ), which correspond to moderately oxidizing conditions. These values are correlated with $\mathrm{Eu} / \mathrm{Eu}^{*}$ vs. $\mathrm{Ce} / \mathrm{Ce}^{*}$ ratio. The $\left[\frac{\mathrm{X}_{e^{4+}}^{\text {melt }}}{X_{\mathrm{C} e^{3+}}^{m e l t}}\right]$ oxybarometer $[70]$ is more accurate as it is independent of the REE, and especially La-content of zircon.

These methods also use factors that are additional sources of uncertainty. The $\left[\frac{X_{\mathrm{Ce}^{4+}}^{\text {melt }}}{\mathrm{X}_{\mathrm{C} e^{3+}}^{\text {ln }}}\right]$ oxybarometer [70] requires melt composition. As melt inclusions are lacking in the study area, whole rock analyses are used as rough approximation of magma composition. However, the studied rocks contain large euhedral plagioclase and amphibole that likely crystallized prior zircon and whole rock chemistry is unlikely representative of the composition of the residual melts in equilibrium with the studied zircons. In order to evaluate the uncertainty associated with a poor estimate of residual melt composition, the Si- and $\mathrm{K}$ - and Ca-contents of the melt were arbitrarily increased prior re-calculating the $\mathrm{fO}_{2}$ parameter. These modifications have little effects on the $f \mathrm{O}_{2}$. For example, a decrease of the Si-content from 60 to $70 \mathrm{wt}$ \%, will cause a diminution of 0.05 of the $\mathrm{fO}_{2}$.

These methods also require insights into the $\mathrm{H}_{2} \mathrm{O}$ content of the melt, the NBO/T parameter, and the temperature of the zircon-saturated melt. To test the sensitivities of the method to these parameters, the $\mathrm{H}_{2} \mathrm{O}$ content of the melt was arbitrarily increased from $3 \%$ to $5 \%$ and this induced a decrease of $1 \log$ unit of the $\mathrm{fO}_{2}$ parameter. In addition, a 0.1 increase of the NBO/T parameter induces a $0.3 \log$ unit increase of the $\mathrm{fO}_{2}$ parameter. Ideally, these parameters should be constrained using melt inclusions, which are lacking in the studied samples. Results of this study thus provide an approximation of 
the $f \mathrm{O}_{2}$ parameter that is, to date, the best available estimation of this parameter for Neoarchean magmatism in the Chibougamau area.

In summary, depending of the quantity of pristine and non-pristine zircon, the $\left[\frac{X_{e^{4+}}^{m e l t}}{X_{C e^{3+}}^{m e l t}}\right]$ oxybarometer seems to be the most reliable method to estimate the $f \mathrm{O}_{2}$ parameter. If no pristine zircons are available, we recommend using the $\mathrm{Eu} / \mathrm{Eu}^{*}$ vs. $\mathrm{Ce} / \mathrm{Ce}^{*}$ ratio in apatite that provides a general estimation of the $\mathrm{fO}_{2}$ parameter. Moreover, this study shows that synvolcanic magmas (Anville intrusion) are more reduced than syntectonic magmas and that syntectonic magmas display similar oxidation states.

\subsection{Consequences for IRGS Exploration}

Among the studied intrusions, only the Lac Line stock is associated with a magmatic-hydrothermal system (IRGS possibly), i.e., Au-Ag-Cu \pm Mo mineralization [11,45]. To evaluate potential Au deposit fertility, the geochemical characteristics (whole rock analyses, $f \mathrm{O}_{2}$, volatile content) of the mineralized Lac Line intrusion will be compared to the other studied intrusions. The synvolcanic Anville intrusion is not included in this comparison as IRGS only form in syntectonic settings.

To provide magmatic-derived fluids to a mineralizing system, an intrusion must likely be volatile-rich. Deuteric alteration, in the Saussure intrusion, is indicated by amphibole pseudomorphosed by chlorite. This points to significant fluid exsolution and circulation in this intrusion, which is essential for IRGS mineralization [74]. In addition, the $\mathrm{H}_{2} \mathrm{O}$ concentration of the Saussure, Chevrillon, and Opémisca intrusions, as estimated using the empirical amphibole formulation [74,75], is within the range of values for hydrated magmas. Magmas of the Chevrillon, Saussure, and Opémisca intrusions, with which apatite and zircon may have equilibrated, yield oxygen fugacity of $\triangle \mathrm{FMQ}-0.7$ to 0.7 and $\mathrm{H}_{2} \mathrm{O}$ concentration of 5.4 to $5.5 \mathrm{wt}$ \% $\% 3.7$ to $4.5 \mathrm{wt} . \%$, and 3.7 to $4.1 \mathrm{wt} . \%$, respectively. Magmas associated with porphyry mineralization display comparable water contents and $f \mathrm{O}_{2}$ [104], except for the Chevrillon intrusion, which display a lower $f \mathrm{O}_{2}$ [7-9].

A magma also has to contain a significant amount of $\mathrm{S}$ and/or $\mathrm{Cl}$ to dissolve and retain $\mathrm{Au}$, as there is a strong linear correlation between $\mathrm{Au}$ solubility and the amount of $\mathrm{Cl}$ and $\mathrm{S}$ dissolved in a magma [8,9]. The studied intrusions are Cl-depleted according to apatite chemistry. However, the Lac Line and Saussure intrusions may contain significant amount of S. With $0.03 \mathrm{wt}$. \% S dissolved in the melt, the maximum amount of $\mathrm{Au}$ that can be dissolved in a felsic melt is $1.2 \mathrm{ppm}$ [9]. In addition, $\mathrm{S}$ speciation has a strong impact on Au solubility. For felsic melts, maximum Au solubility is reached for $f \mathrm{O}_{2}$ ranging from $\mathrm{FMQ}+0.5$ to $\mathrm{FMQ}+1.5$ [8]. In the studied syntectonic intrusions, the $f \mathrm{O}_{2}$ measured from zircon of the Saussure intrusion allows optimal Au solubility, meaning that, if Au was available, the magmatic system may have accumulated Au.

\subsection{Melts Sources and Oxygen Fugacity}

In this study, the intrusions are mostly generated from TTG and alkaline to subalkaline melts. The source of TTG is an enriched and hydrated mafic rock and partial melting occurred at high pressure, i.e., within the stability field of garnet $(10-12$ kbar) $[105,106]$. These mafic rocks are likely hydrated on the sea floor and then retain part of their water during metamorphism.

The petrogenesis of syntectonic magmatism remains controversial [19]. Alkaline magmas likely come from low degree partial melting of an enriched ultramafic component, which generally corresponds to a metasomatized mantle [107]. The sources of calc-alkaline and other magmas of the syntectonic period likely display a range of crustal and mantle components [19]. These magmas also evolve through several processes, such as fractional crystallization, assimilation, or mixing, and differentiate to intermediate to felsic-oxidized magmas, such as HKCA and sanukitoid [19]. The relative importance of source composition and differentiation process in producing the chemical diversity observed in syntectonic intrusions remains debated [15]. However, and regarding source composition, the elevated $f \mathrm{O}_{2}$ measured in the studied alkaline and subalkaline syntectonic magmas 
gives additional support to Neoarchean metasomatized mantle as a possible source of at least part of syntectonic magmas.

\section{Conclusions}

The aim to this study was to estimate the under-measured geochemical parameters $\left(f \mathrm{O}_{2}\right.$, volatile content) of syntectonic magmas. For this reason, the oxygen fugacity, and volatile contents of the melt were measured using both apatite and zircon chemistry to determine which method is more suited for the study of Archean magmas. This study reveals that:

- Apatite and zircon are useful to estimate the oxygen fugacity depending on the mineral quality, but further investigations are needed to efficiently measure the $f \mathrm{O}_{2}$ parameter of a melt using apatite chemistry;

- There is an increase of the $f \mathrm{O}_{2}$ parameter between the synvolcanic and syntectonic periods of the Abitibi Subprovince;

- The studied part of the Anville intrusion was emplaced during the same period as the Chrissie and Des Vents formations, which makes it the oldest subvolcanic complex of the Abitibi Subprovince. Moreover, geochronological analyses of the undated Saussure and Chevrillon intrusions, as well as their stratigraphic relationships with syntectonic sedimentary basins, confirms that they are both syntectonic intrusions;

- Magmas from the Saussure intrusion have the optimal $f \mathrm{O}_{2}$ for Au transportation. Moreover, the magma from the Saussure and Lac Line intrusions may have contributed S-rich mineralizing fluids to magmatic-hydrothermal systems. As such, further investigations are needed to evaluate the Au-content of the melt and the size of the magmatic system, and to evaluate the economic potential of the studied intrusions.

Supplementary Materials: The following are available online at http://www.mdpi.com/2075-163X/10/11/966/s1, Table S1: the microprobe and LA-ICP-MS analysis of amphibole, apatite, and zircon. Table S2: the different calculations used in this study. Table S3: the process used for the geochronology.

Author Contributions: Conceptualization, methodology, writing-original draft preparation, B.M., L.M., J.H.M.; writing-review and editing, B.M., L.M., J.H.M. All authors have read and agreed to the published version of the manuscript.

Funding: This study was undertaken as part of the Metal Earth project (Laurentian University) investigation of the Chibougamau area. This research was funded by the Canada First Research Excellence Funds and federal/provincial/industry partners (http://merc.laurentian.ca/research/metal-earth/). Funding for LA-ICP-MS instrumentation and analyses at the Mineral Exploration Research Centre was provided by the Canada First Research Excellence Fund - Metal Earth research initiative. This project was also funded by the NSERC (Natural Sciences and Engineering Research Council) Discovery Grant to L. Mathieu (Reference number RGPIN-2018-06325).

Acknowledgments: Many thanks to assistant editor Bojana Simic and to the three anonymous reviewers whose comments greatly contributed to improve the quality of this manuscript. Warm thanks are addressed to all of the researchers that discussed Archean magmatism with the authors through the years. The authors also address thanks to MERN and OGS for their remarkable dataset. Many thanks to Laura Quintini for her support and reviewing. This paper is Metal Earth contribution number MERC-ME-2020-069.

Conflicts of Interest: The authors declare no conflict of interest.

\section{References}

1. Lang, J.R.; Baker, T.; Hart, C.; Mortensen, J. An exploration model for intrusion-related gold systems. Soc. Econ. Geol. Newsl. 2000, 40, 6-15.

2. Hart, C.J.R. Reduced intrusion-related gold systems. In Mineral deposits of Canada: A Synthesis of Major Deposit Types, District Metallogeny, the Evolution of Geological Provinces, and Exploration Methods; Goodfellow, W.D., Ed.; Special Publication No. 5; Geological Association of Canada, Mineral Deposits Division: Saint John's, NL, Canada, 2007; pp. 95-112. 
3. De Souza, S.; Dubé, B.; McNicoll, V.J.; Dupuis, C.; Mercier-Langevin, P.; A Creaser, R.; Kjarsgaard, I.M. Geology, hydrothermal alteration, and genesis of the world-class Canadian Malartic stockwork-disseminated Archean gold deposit, Abitibi, Quebec. Target. Geosci. Initiat. 2015, 4, 113-126. [CrossRef]

4. Hart, C.; Goldfarb, R. Distinguishing intrusion-related from orogenic gold systems. In Proceedings of the New Zealand Minerals Conference, Auckland, New Zealand, 13-16 November 2005.

5. Bigot, L.; Jébrak, M. Gold Mineralization at the Syenite-Hosted Beattie Gold Deposit, Duparquet, Neoarchean Abitibi Belt, Canada. Econ. Geol. 2015, 110, 315-335. [CrossRef]

6. Mathieu, L. Quantifying hydrothermal alteration with normative minerals and other chemical tools at the Beattie Syenite, Abitibi greenstone belt, Canada. Geochem. Explor. Environ. Anal. 2016, 16, 233-244. [CrossRef]

7. Botcharnikov, R.E.; Holtz, F.; Mungall, J.E.; Beermann, O.; Linnen, R.L.; Garbe-Schönberg, D. Behavior of gold in a magma at sulfide-sulfate transition: Revisited. Am. Miner. 2013, 98, 1459-1464. [CrossRef]

8. Botcharnikov, R.E.; Linnen, R.L.; Wilke, M.; Holtz, F.; Jugo, P.J.; Berndt, J. High gold concentrations in sulphide-bearing magma under oxidizing conditions. Nat. Geosci. 2010, 4, 112-115. [CrossRef]

9. Botcharnikov, R.; Linnen, R.; Holtz, F. Solubility of Au in Cl- and S-bearing hydrous silicate melts. Geochim. Cosmochim. Acta 2010, 74, 2396-2411. [CrossRef]

10. Mathieu, L.; Racicot, D. Petrogenetic Study of the Multiphase Chibougamau Pluton: Archaean Magmas Associated with Cu-Au Magmato-Hydrothermal Systems. Minerals 2019, 9, 174. [CrossRef]

11. Côté-Mantha, O. Architecture et Origine du Système de Minéralisation Polymétallique du Secteur lac Line, Région de Chibougamau, Québec; Université du Québec à Chicoutimi: Chicoutimi, QC, Canada, 2009. [CrossRef]

12. Lépine, S. Le gîte à $\mathrm{Au-Cu-Mo} \mathrm{de} \mathrm{MOP-II} \mathrm{(Chibougamau,} \mathrm{Québec):} \mathrm{Un} \mathrm{Porphyre} \mathrm{Archéen} \mathrm{Déformé.}$ Mémoire. Montréal (Québec, Canada); Université du Québec à Montréal, Maîtrise en Sciences de la Terre: Montréal, QC, Canada, 2009.

13. Mathieu, L.; Crépon, A.; Kontak, D.J. Tonalite-Dominated Magmatism in the Abitibi Subprovince, Canada, and Significance for Cu-Au Magmatic-Hydrothermal Systems. Minerals 2020, 10, 242. [CrossRef]

14. Mathieu, L.; Snyder, D.B.; Bedeaux, P.; Cheraghi, S.; Lafrance, B.; Thurston, P.; Sherlock, R. Deep Into the Chibougamau Area, Abitibi Greenstone Belt: Structure of a Neoarchean Crust Revealed by Seismic Reflection Profiling. Tectonics 2020, 39, e2020TC006223. [CrossRef]

15. Laurent, O.; Martin, H.; Moyen, J.-F.; Doucelance, R. The diversity and evolution of late-Archean granitoids: Evidence for the onset of "modern-style" plate tectonics between 3.0 and 2.5Ga. Lithos 2014, 205, 208-235. [CrossRef]

16. Thurston, P.C.; Ayer, J.A.; Goutier, J.; Hamilton, M. Depositional Gaps in Abitibi Greenstone Belt Stratigraphy: A Key to Exploration for Syngenetic Mineralization. Econ. Geol. 2008, 103, 1097-1134. [CrossRef]

17. Dubé, B.; Gosselin, P. Greenstone-hosted quartz-carbonate vein deposits. In Mineral Deposits of Canada: A Synthesis of Major Deposit-Types, District Metallogeny, the Evolution of Geological Provinces, and Exploration Methods; Goodfellow, W.D., Ed.; Special Publication No. 5; Geological Association of Canada, Mineral Deposits Division: Saint John's, NL, Canada, 2007; Volume 5, pp. 49-73.

18. Bleeker, W. Synorogenic gold mineralization in granite-greenstone terranes: the deep connection between extension, major faults, synorogenic clastic basins, magmatism, thrust inversion, and long-term preservation. Target. Geosci. Initiat. 2015, 4, 25-47.

19. Moyen, J.-F. Archean granitoids: Classification, petrology, geochemistry and origin. Geol. Soc. London Spéc. Publ. 2019, 489. [CrossRef]

20. Robert, F. Syenite-associated disseminated gold deposits in the Abitibi greenstone belt, Canada. Miner. Depos. 2001, 36, 503-516. [CrossRef]

21. Stern, R.A.; Hanson, G.N.; Shirey, S.B. Petrogenesis of mantle-derived, LILE-enriched Archean monzodiorites and trachyandesites (sanukitoids) in southwestern Superior Province. Can. J. Earth Sci. 1989, 26, 1688-1712. [CrossRef]

22. Leclerc, F.; Roy, P.; Houle, P.; Pilote, P.; Bédard, J.H.; Harris, L.B.; McNicoll, V.J.; Van Breemen, O.; David, J.; Goulet, N. Géologie de la Région de Chibougamau; Direction Générale de Géologie Québec: Québec, QC, Canada, 2017; RG 2015-03.

23. Davis, D.W.; Simard, M.; Hammouche, H.; Bandyayera, D.; Goutier, J.; Pilote, P.; Leclerc, F.; Dion, C. Datations U-Pb Effectuées Dans les Provinces du Supérieur et de Churchill en 2011-2012; RP 2014-05; Ministère des Ressources naturelles: Québec, QC, Canada, 2014; p. 62. 
24. David, J.; Mcnicoll, V.; Simard, M.; Bandyayera, D.; Hammouche, H.; Goutier, J.; Pilote, P.; Rhéaume, P.; Leclerc, F.; Dion, C. Datations U-Pb Effectuées Dans les Provinces du Supérieur et de Churchill en 2009-2010; RP 2011-02; Ministère des Ressources naturelles et de la Faune: Québec, QC, Canada, 2011; p. 37.

25. Mortensen, J.K. U-Pb geochronology of the eastern Abitibi Subprovince. Part 1: Chibougamau-Matagami-Joutel region. Can. J. Earth Sci. 1993, 30, 11-28. [CrossRef]

26. David, J.; Simard, M.; Bandyayera, D.; Goutier, J.; Hammouche, H.; Pilote, P.; Leclerc, F.; Dion, C. Datations U-Pb effectuées dans les provinces du Supérieur et de Churchill en 2010-2011. MRNF. RP 2012-01, 33 pages. Available online: http://gq.mines.gouv.qc.ca/documents/EXAMINE/RP201201 (accessed on 1 September 2019).

27. Leclerc, F.; Harris, L.B.; Bédard, J.H.; dard, J.H.; Van Breemen, O.; Goulet, N. Structural and Stratigraphic Controls on Magmatic, Volcanogenic and Syn-Tectonic Mineralization in the Chapais-Chibougamau Mining Camp, Northeastern Abitibi, Canada. Econ. Geol. 2012, 107, 963-989.

28. Chown, E.H.; Daigneault, R.; Mueller, W.; Mortensen, J.K. Tectonic evolution of the Northern Volcanic Zone, Abitibi belt, Quebec. Can. J. Earth Sci. 1992, 29, 2211-2225. [CrossRef]

29. Legault, M.I. Environnement Métallogénique du Couloir de Fancamp avec Emphase sur les Gisements Aurifères de Chevrier, Région de Chibougamau, Québec. Ph.D. Thesis, Université du Québec à Chicoutimi, Chicoutimi, QC, Canada, 2003.

30. Marie, K. Metal Earth à Chibougamau: Géochimie, Géométrie et Mode de Mise en Place du Complexe d'Eau Jaune; Mémoire de maîtrise, Université du Québec à Chicoutimi: Chicoutimi, QC, Canada, 2019.

31. David, J.; Davis, D.W.; Dion, C.; Goutier, J.; Legault, M.; Roy, P. Datations U-Pb effectuees dans la Sous-province de l'Abitibi en 2005-2006; MRNF. RP 2007-01; Technical report for Ministère des Ressources naturelles et de la Faune: Quebec, QC, Canada, 2007.

32. Caty, J.L. Canton de Richardson (comte d'Abitibi-est)—Rapport Interimaire; Ministère des Richesses naturelles du Québec: Quebec, QC, Canada, 1978; p. 38.

33. Charbonneau, J.M.; Picard, C.; Dupuis-Hebert, L. Synthese geologique de la region de Chapais-Branssat (ABITIBI); MM 88-01; Gouvernement du Québec: Quebec, QC, Canada, 1991; p. 202.

34. Pierre, S. Pétrographie, Sédimentologie et Analyse des Facies de la Formation de Daubrée, Chapais, Québec; Mémoire de maîtrise, Université du Québec à Chicoutimi: Chicoutimi, QC, Canada, 1986.

35. McNicoll, V.; Goutier, J. datations U-Pb de la région du lac au Goéland, Sous-province de l'Abitibi, RP $2008-02$. In Ressources Naturelles et faune Québec; Quebec, QC, Canada, 2008.

36. Leclerc, F.; Bédard, J.H.; Harris, L.B.; McNicoll, V.J.; Goulet, N.; Roy, P.; Houle, P. Tholeiitic to calc-alkaline cyclic volcanism in the Roy Group, Chibougamau area, Abitibi Greenstone Belt-Revised stratigraphy and implications for VHMS explorationGeological Survey of Canada Contribution 20100254. Ministère des Ressources naturelles et de la Faune Contribution 8439-2010-2011-17. Can. J. Earth Sci. 2011, 48, 661-694. [CrossRef]

37. Frarey, M.J.; E Krogh, T. UPb Zircon Ages of Late Internal Plutons of the Abitibi and eastern Wawa Subprovinces, Ontario and Quebec. Curr. Res. Part A Geol. Surv. Can. 1986, 86, 43-48. [CrossRef]

38. Gariépy, C.; Allègre, C.J. The lead isotope geochemistry and geochronology of late-kinematic intrusives from the Abitibi greenstone belt, and the implications for late Archaean crustal evolution. Geochim. Cosmochim. Acta 1985, 49, 2371-2383. [CrossRef]

39. Allard, G.O.; Caty, J.-L.; Gobeil, A. The Archean supracrustal rocks of the Chibougamau area. In Evolution of Archean Supracrustal Sequences; Ayres, L.D., Thurston, P.D., Card, K.D., Weber, W., Eds.; Special Paper 28; Geological Association of Canada: Saint John's, NL, Canada, 1985; pp. 55-63.

40. Moisan, A. Petrochimie des gres de la Formation de Bordeleau Chibougamau Quebec. Master's Thesis, Département des Sciences de la Terre, Université du Québec à Chicoutimi, Chicoutimi, QC, Canada, 1992. [CrossRef]

41. Huguet, J. Pétrographie et géochimie du Pluton de Chevrillon et relation structurale avec le Groupe d'Opémisca (région de Chibougamau, Québec); Mémoire de maîtrise, Université du Québec à Chicoutimi: Chicoutimi, QC, Canada, 2019.

42. Gervais, D. Le caractère de la zone de contact entre l'intrusion tonalitique syn-à postcinématique d'Anville et le terrain de gneiss du Massif de Lapparent; projet de fin d'études; Université du Québec à Chicoutimi: Chicoutimi, QC, Canada, 1986; p. 56.

43. Midra, R.; Chown, E.H.; Tait, L. Géologie de la region du lac Dickson (Bande Caopatina-Desmaraisville); MB 91-30; Ministère de l’Énergie et des Ressources: Québec, QC, Canada, 1992; p. 65. 
44. Thiboutot, H.; Rouillard, M. Rapport géologique sur Saussure; service du potentiel mineral; Ministère de l’Energie et des ressources, Gouvernement du Québec: Québec, QC, Canada, 1981.

45. Pilote, P. Stratigraphie et signification des minéralisations dans le secteur du mont Bourbeau, canton de McKenzie, Chibougamau; mémoire de maîtrise; Université du Québec à Chicoutimi: Chicoutimi, QC, Canada, 1986; p. 182.

46. Wolhuter, L.E. Le pluton d'Opémisca, une étude pétrologique et géochimique; Ministère des richesses naturelles du Québec, direction générale des mines: Québec, QC, Canada, 1971.

47. Wolhuter, L.E. Géologie des quarts NW, SW et SE du canton de Lévy et du quart SE du canton de Daubrée; MB 84-05; Energie et Ressources, Direction de la Recherche Géologique: Québec, QC, Canada, 1984.

48. Augland, L.E.; David, J.; Pilote, P.; Leclerc, F.; Goutier, J.; Hammouche, H.; Lafrance, I.; Talla Takam, F.; Deschênes, P.L.; Guemache, M. Datations $U-P b$ dans les provinces de Churchill et du Supérieur effectuées au GÉOTOP en 2012-2013; RP 2015-01; Ministère de l’Énergie et des Ressources Naturelles: Québec, QC, Canada, 2016; p. 43.

49. Harmon, R.S.; Lawley, C.J.; Watts, J.; Harraden, C.L.; Somers, A.M.; Hark, R.R. Laser-Induced Breakdown Spectroscopy-An Emerging Analytical Tool for Mineral Exploration. Minerals 2019, 9, 718. [CrossRef]

50. Gladney, E.S.; Roelandts, I. Distribution of NBS, USGS and CCRMP Reference Material Data in the Literature (1951-1985). Geostand. Newsl. 1987, 11, 133-142. [CrossRef]

51. Loader, M.A.; Wilkinson, J.J.; Armstrong, R. The effect of titanite crystallisation on Eu and Ce anomalies in zircon and its implications for the assessment of porphyry Cu deposit fertility. Earth Planet. Sci. Lett. 2017, 472, 107-119. [CrossRef]

52. SIGEOM Système d'information géominière du Québec. Available online: http://sigeom.mines.gouv.qc.ca (accessed on 1 January 2019).

53. Whitney, D.L.; Evans, B.W. Abbreviations for names of rock-forming minerals. Am. Miner. 2009, 95, 185-187. [CrossRef]

54. Chew, D.M.; Babechuk, M.G.; Cogné, N.; Mark, C.; O’Sullivan, G.J.; Henrichs, I.A.; Doepke, D.; McKenna, C.A. (LA,Q)-ICPMS trace-element analyses of Durango and McClure Mountain apatite and implications for making natural LA-ICPMS mineral standards. Chem. Geol. 2016, 435, 35-48. [CrossRef]

55. Jochum, K.P.; Weis, U.; Stoll, B.; Kuzmin, D.; Yang, Q.; Raczek, I.; Jacob, D.E.; Stracke, A.; Birbaum, K.; Frick, D.A.; et al. Determination of Reference Values for NIST SRM 610-617 Glasses Following ISO Guidelines. Geostand. Geoanalytical Res. 2011, 35, 397-429. [CrossRef]

56. Zeh, A.; Stern, R.A.; Gerdes, A. The oldest zircons of Africa-Their U-Pb-Hf-O isotope and trace element systematics, and implications for Hadean to Archean crust-mantle evolution. Precambrian Res. 2014, 241, 203-230. [CrossRef]

57. Turlin, F.; Turlin, F.; Gervais, F.; André-Mayer, A.-S.; Moukhsil, A.; Zeh, A.; André-Mayer, A.-S.; Iptn, I. Petrogenesis of LREE-rich pegmatitic granite dykes in the central Grenville Province by partial melting of Paleoproterozoic-Archean metasedimentary rocks: Evidence from zircon U-Pb-Hf-O isotope and trace element analyses. Precambrian Res. 2019, 327, 327-360. [CrossRef]

58. Groulier, P.-A.; Turlin, F.; André-Mayer, A.-S.; Ohnenstetter, D.; Crépon, A.; Boulvais, P.; Poujol, M.; Rollion-Bard, C.; Zeh, A.; Moukhsil, A.; et al. Silicate-Carbonate Liquid Immiscibility: Insights from the Crevier Alkaline Intrusion (Quebec). J. Pet. 2020, 61. [CrossRef]

59. Geisler, T.; Schaltegger, U.; Tomaschek, F. Re-equilibration of Zircon in Aqueous Fluids and Melts. Elements 2007, 3, 43-50. [CrossRef]

60. McDonough, W.; Sun, S.S. The composition of the Earth. Chem. Geol. 1995, 67, 1050-1056. [CrossRef]

61. Ferry, J.M.; Watson, E.B. New thermodynamic models and revised calibrations for the Ti-in-zircon and Zr-in-rutile thermometers. Contrib. Miner. Pet. 2007, 154, 429-437. [CrossRef]

62. Hayden, L.A.; Watson, E.B. Rutile saturation in hydrous siliceous melts and its bearing on Ti-thermometry of quartz and zircon. Earth Planet. Sci. Lett. 2007, 258, 561-568. [CrossRef]

63. Shen, P.; Hattori, K.; Pan, H.; Jackson, S.; Seitmuratova, E. Oxidation Condition and Metal Fertility of Granitic Magmas: Zircon Trace-Element Data from Porphyry Cu Deposits in the Central Asian Orogenic Belt. Econ. Geol. 2015, 110, 1861-1878. [CrossRef]

64. Cao, M.; Li, G.; Qin, K.; Seitmuratova, E.Y.; Liu, Y. Major and Trace Element Characteristics of Apatites in Granitoids from Central Kazakhstan: Implications for Petrogenesis and Mineralization. Resour. Geol. 2011, 62, 63-83. [CrossRef] 
65. Drake, M.J. The oxidation state of europium as an indicator of oxygen fugacity. Geochim. Cosmochim. Acta 1975, 39, 55-64. [CrossRef]

66. Sha, L.-K.; Chappell, B.W. Apatite chemical composition, determined by electron microprobe and laser-ablation inductively coupled plasma mass spectrometry, as a probe into granite petrogenesis. Geochim. et Cosmochim. Acta 1999, 63, 3861-3881. [CrossRef]

67. Azadbakht, Z.; Lentz, D.; McFarlane, C.R.M. Apatite Chemical Compositions from Acadian-Related Granitoids of New Brunswick, Canada: Implications for Petrogenesis and Metallogenesis. Minerals 2018, 8 , 598. [CrossRef]

68. Trail, D.; Watson, E.B.; Tailby, N.D. Ce and Eu anomalies in zircon as proxies for the oxidation state of magmas. Geochim. Cosmochim. Acta 2012, 97, 70-87. [CrossRef]

69. Trail, D.; Watson, E.B.; Tailby, N.D. The oxidation state of Hadean magmas and implications for early Earth's atmosphere. Nat. Cell Biol. 2011, 480, 79-82. [CrossRef] [PubMed]

70. Smythe, D.J.; Brenan, J.M. Magmatic oxygen fugacity estimated using zircon-melt partitioning of cerium. Earth Planet. Sci. Lett. 2016, 453, 260-266. [CrossRef]

71. Smythe, D.J.; Brenan, J.M. Cerium oxidation state in silicate melts: Combined f O 2, temperature and compositional effects. Geochim. Cosmochim. Acta 2015, 170, 173-187. [CrossRef]

72. Zou, X.; Qin, K.; Han, X.; Li, G.; Evans, N.J.; Li, Z.; Yang, W. Insight into zircon REE oxy-barometers: A lattice strain model perspective. Earth Planet. Sci. Lett. 2019, 506, 87-96. [CrossRef]

73. Li, W.; Yang, Z.; Cao, K.; Lu, Y.; Sun, M. Redox-controlled generation of the giant porphyry Cu-Au deposit at Pulang, southwest China. Contrib. Miner. Pet. 2019, 174, 12. [CrossRef]

74. Mair, J.L.; Farmer, G.L.; Groves, D.I.; Hart, C.J.R.; Goldfarb, R.J. Petrogenesis of Postcollisional Magmatism at Scheelite Dome, Yukon, Canada: Evidence for a Lithospheric Mantle Source for Magmas Associated with Intrusion-Related Gold Systems. Econ. Geol. 2011, 106, 451-480. [CrossRef]

75. Ridolfi, F.; Renzulli, A.; Puerini, M. Stability and chemical equilibrium of amphibole in calc-alkaline magmas: An overview, new thermobarometric formulations and application to subduction-related volcanoes. Contrib. Miner. Pet. 2009, 160, 45-66. [CrossRef]

76. Virgo, D.; Mysen, B.O.; Kushiro, I. Anionic Constitution of 1-Atmosphere Silicate Melts: Implications for the Structure of Igneous Melts. Science 1980, 208, 1371-1373. [CrossRef]

77. Le Bas, M.J.; Le Maitre, R.W.; Woolley, A.R. The construction of the Total Alkali-Silica chemical classification of volcanic rocks. Miner. Pet. 1992, 46,1-22. [CrossRef]

78. Middlemost, E.A.K. Magmas and Magmatic Rocks. An Introduction to Igneous Petrology. x +266 pp. London, New York: Longman. ISBN 058230080 0. Geol. Mag. 1986, 123, 87-88. [CrossRef]

79. Shand, S.J. The Eruptive Rocks, 2nd ed.; John Wiley: New York, NY, USA, 1943; p. 444.

80. Corfu, F.; Hanchar, J.M.; Hoskin, P.W.; Kinny, P. Atlas of Zircon Textures. Rev. Miner. Geochem. 2003, 53, 469-500. [CrossRef]

81. Scherer, E.E.; Whitehouse, M.J.; Munker, C. Zircon as a Monitor of Crustal Growth. Elements 2007, 3, $19-24$. [CrossRef]

82. Hawthorne, F.C.; Oberti, R.; Harlow, G.E.; Maresch, W.V.; Martin, R.F.; Schumacher, J.C.; Welch, M.D. Nomenclature of the amphibole supergroup. Am. Miner. 2012, 97, 2031-2048. [CrossRef]

83. Piccoli, P.M.; Candela, P.A. Apatite in Igneous Systems. Rev. Miner. Geochem. 2002, 48, 255-292. [CrossRef]

84. Parat, F.; Holtz, F.; Streck, M.J. Sulfur-bearing Magmatic Accessory Minerals. Rev. Miner. Geochem. 2011, 73, 285-314. [CrossRef]

85. Li, H.; Hermann, J. Chlorine and fluorine partitioning between apatite and sediment melt at $2.5 \mathrm{GPa}, 800{ }^{\circ} \mathrm{C}$ : A new experimentally derived thermodynamic model. Am. Miner. 2017, 102, 580-594. [CrossRef]

86. Chelle-Michou, C.; Chiaradia, M. Amphibole and apatite insights into the evolution and mass balance of $\mathrm{Cl}$ and S in magmas associated with porphyry copper deposits. Contrib. Miner. Pet. 2017, 172, 105. [CrossRef]

87. Martin, H.; Moyen, J.-F.; Rapp, R. The sanukitoid series: Magmatism at the Archaean-Proterozoic transition. Trans. Royal Soc. Edinb. 2009, 100, 15-33. [CrossRef]

88. Mondal, M.; Raza, A. Geochemistry of sanukitoid series granitoids from the Neoarchaean Berach granitoid batholiths, Aravalli craton, northwestern Indian shield. Curr. Sci. 2013, 105, 102-108.

89. Exley, R. Microprobe studies of REE-rich accessory minerals: Implications for Skye granite petrogenesis and REE mobility in hydrothermal systems. Earth Planet. Sci. Lett. 1980, 48, 97-110. [CrossRef] 
90. Cave, B.; Lilly, R.; Glorie, S.; Gillespie, J. Geology, Apatite Geochronology, and Geochemistry of the Ernest Henry Inter-Lens: Implications for a Re-Examined Deposit Model. Minerals 2018, 8, 405. [CrossRef]

91. Panina, L.I.; Rokosova, E.Y.; Isakova, A.T.; Tolstov, A.V. Lamprophyres of the Tomtor Massif: A result of mixing between potassic and sodic alkaline mafic magmas. Petrology 2016, 24, 608-625. [CrossRef]

92. Harlov, D.E.; Andersson, U.B.; Förster, H.-J.; Nyström, J.O.; Dulski, P.; Broman, C. Apatite-monazite relations in the Kiirunavaara magnetite-apatite ore, northern Sweden. Chem. Geol. 2002, 191, 47-72. [CrossRef]

93. Zhong, S.; Feng, C.; Seltmann, R.; Li, D.; Qu, H. Can magmatic zircon be distinguished from hydrothermal zircon by trace element composition? The effect of mineral inclusions on zircon trace element composition. Lithos 2018, 314-315, 646-657. [CrossRef]

94. Yang, W.-B.; Niu, H.-C.; Shan, Q.; Sun, W.-D.; Zhang, H.; Li, N.-B.; Jiang, Y.-H.; Yu, X.-Y. Geochemistry of magmatic and hydrothermal zircon from the highly evolved Baerzhe alkaline granite: Implications for Zr-REE-Nb mineralization. Miner. Deposita 2013, 49, 451-470. [CrossRef]

95. Geisler, T.; Pidgeon, R.T.; Kurtz, R.; Van Bronswijk, W.; Schleicher, H. Experimental hydrothermal alteration of partially metamict zircon. Am. Miner. 2003, 88, 1496-1513. [CrossRef]

96. Hoskin, P.W. Trace-element composition of hydrothermal zircon and the alteration of Hadean zircon from the Jack Hills, Australia. Geochim. et Cosmochim. Acta 2005, 69, 637-648. [CrossRef]

97. Hoskin, P.W.O.; Schaltegger, U. The composition of zircon and igneous and metamorphic petrogenesis. Rev. Miner. Geochem. 2003, 53, 25-104. [CrossRef]

98. Nutman, A.P.; Maciejowski, R.; Wan, Y. Protoliths of enigmatic Archaean gneisses established from zircon inclusion studies: Case study of the Caozhuang quartzite, E. Hebei, China. Geosci. Front. 2014, 5, 445-455. [CrossRef]

99. Fu, B.; Page, F.Z.; Cavosie, A.J.; Fournelle, J.; Kita, N.T.; Lackey, J.S.; Wilde, S.A.; Valley, J.W. Ti-in-zircon thermometry: Applications and limitations. Contrib. Miner. Pet. 2008, 156, 197-215. [CrossRef]

100. Watson, E.B.; Wark, D.A.; Thomas, J.B. Crystallization thermometers for zircon and rutile. Contrib. Miner. Pet. 2006, 151, 413-433. [CrossRef]

101. Mathieu, L.; Madon, B.; Hamilton, M.A. Physico-chemical parameters of Neoarchean syntectonic magmatism: The example of the Muscocho Pluton, Abitibi Subprovince. Ore Geol. Rev. 2020, 125, 103670. [CrossRef]

102. Blundy, J.; Cashman, K. Ascent-driven crystallisation of dacite magmas at Mount St Helens, 1980-1986. Contrib. Miner. Pet. 2001, 140, 631-650. [CrossRef]

103. Blundy, J.; Cashman, K. Petrologic Reconstruction of Magmatic System Variables and Processes. Rev. Miner. Geochem. 2008, 69, 179-239. [CrossRef]

104. Li, J.-X.; Qin, K.-Z.; Li, G.-M.; Evans, N.J.; Zhao, J.-X.; Yue, Y.-H.; Xie, J. Volatile variations in magmas related to porphyry $\mathrm{Cu}-\mathrm{Au}$ deposits: Insights from amphibole geochemistry, Duolong district, central Tibet. Ore Geol. Rev. 2018, 95, 649-662. [CrossRef]

105. Martin, H.; Moyen, J.-F.; Guitreau, M.; Blichert-Toft, J.; Le Pennec, J.-L. Why Archaean TTG cannot be generated by MORB melting in subduction zones. Lithos 2014, 1-13. [CrossRef]

106. Moyen, J.-F. The composite Archaean grey gneisses: Petrological significance, and evidence for a non-unique tectonic setting for Archaean crustal growth. Lithos 2011, 123, 21-36. [CrossRef]

107. Morris, E.M.; Pasteris, J.D. Mantle Metasomatism and Alkaline Magmatism; Geological Society of America: Boulder, CO, USA, 1987. [CrossRef]

Publisher's Note: MDPI stays neutral with regard to jurisdictional claims in published maps and institutional affiliations.

(C) 2020 by the authors. Licensee MDPI, Basel, Switzerland. This article is an open access article distributed under the terms and conditions of the Creative Commons Attribution (CC BY) license (http://creativecommons.org/licenses/by/4.0/). 